Prepared in cooperation with the Bureau of Reclamation

\title{
Major Hydrostratigraphic Contacts of the Truxton Basin and Hualapai Plateau, Northwestern Arizona, Developed from Airborne Electromagnetic Data
}

Chapter D of

Geophysical Surveys, Hydrogeologic Characterization, and Groundwaterflow Model for the Truxton Basin and Hualapai Plateau, Northwestern Arizona

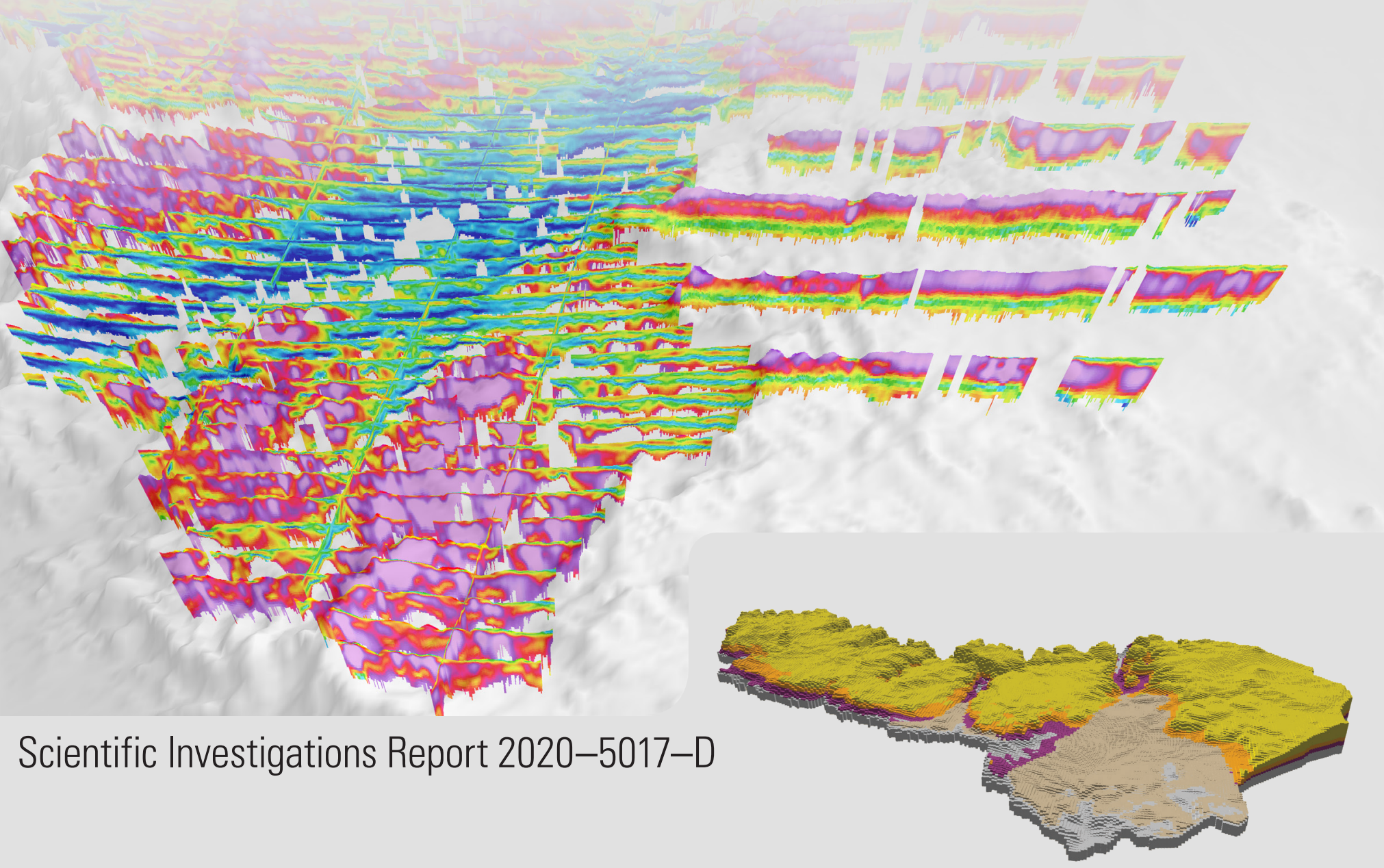


Cover background. Three-dimensional perspective of inverted resistivity sections in the Truxton basin and surrounding area.

Cover insert. Three-dimensional perspective of the Truxton Basin Hydrologic Model viewing the Truxton basin and surrounding area from the south. 


\section{Major Hydrostratigraphic Contacts of the Truxton Basin and Hualapai Plateau, Northwestern Arizona, Developed from Airborne Electromagnetic Data}

By Lyndsay B. Ball

Chapter D of

Geophysical Surveys, Hydrogeologic Characterization, and Groundwaterflow Model for the Truxton Basin and Hualapai Plateau, Northwestern Arizona

Edited by Jon P. Mason

Prepared in cooperation with the Bureau of Reclamation

Scientific Investigations Report 2020-5017-D 


\title{
U.S. Department of the Interior DAVID BERNHARDT, Secretary
}

\author{
U.S. Geological Survey \\ James F. Reilly II, Director
}

\section{U.S. Geological Survey, Reston, Virginia: 2020}

For more information on the USGS - the Federal source for science about the Earth, its natural and living resources, natural hazards, and the environment-visit https://www.usgs.gov or call 1-888-ASK-USGS.

For an overview of USGS information products, including maps, imagery, and publications, visit https://store.usgs.gov.

Any use of trade, firm, or product names is for descriptive purposes only and does not imply endorsement by the U.S. Government.

Although this information product, for the most part, is in the public domain, it also may contain copyrighted materials as noted in the text. Permission to reproduce copyrighted items must be secured from the copyright owner.

Suggested citation:

Ball, L.B., 2020, Major hydrostratigraphic contacts of the Truxton basin and Hualapai Plateau, northwestern Arizona, developed from airborne electromagnetic data, chap. D of Mason, J.P., ed., Geophysical surveys, hydrogeologic characterization, and groundwater flow model for the Truxton basin and Hualapai Plateau, northwestern Arizona: U.S. Geological Survey Scientific Investigations Report 2020-5017, 24 p., https://doi.org/10.3133/sir20205017D.

Associated data for this publication:

Ball, L.B., Bills, D.J., and Macy, J.P., 2020, Airborne electromagnetic and magnetic survey data from the western Hualapai Indian Reservation near Grand Canyon West and Peach Springs, Arizona, 2018: U.S. Geological Survey data release, https://doi.org/10.5066/P910LJN3.

ISSN 2328-0328 (online) 


\section{Contents}

Abstract

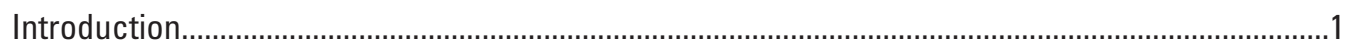

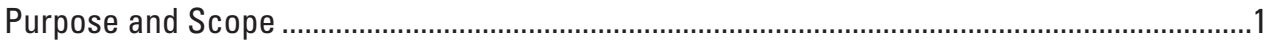

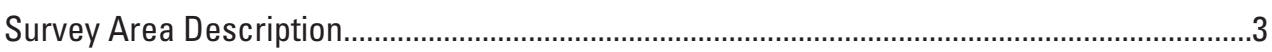

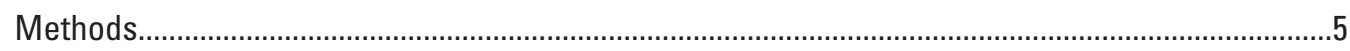

Airborne Geophysical Data Acquisition, Processing, and Inversion .......................................

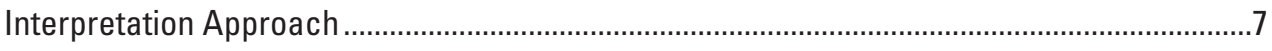

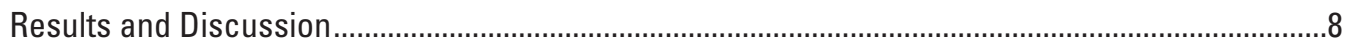

Regional Resistivity Structure ...............................................................................................

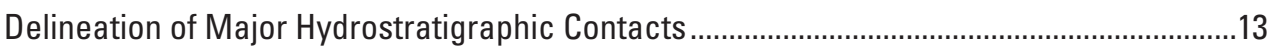

Muav Limestone-Bright Angel Shale Contact ..................................................................13

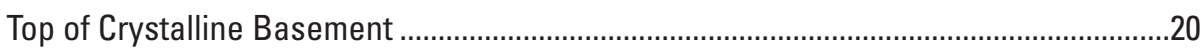

Interpretational Uncertainty and Alternative Structural Scenarios.................................21

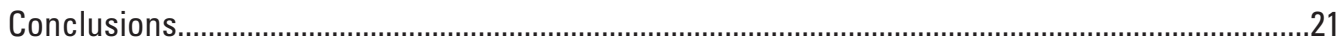

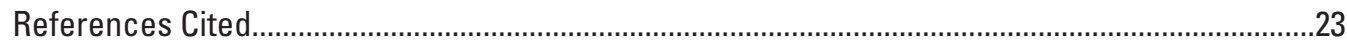

\section{Figures}

1. Map of the Grand Canyon West airborne geophysical survey area showing flight lines, the groundwater model extent, the Truxton basin, and major

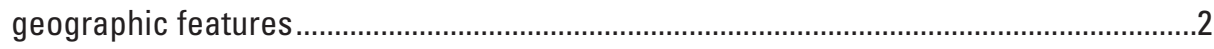

2. Map of the Grand Canyon West airborne geophysical survey area showing flight lines and regional geologic units and structures .........................................................5

3. Sections of smooth inverted resistivity models for selected flight lines with mapped

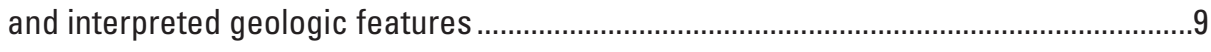

4. Maps showing smooth inverted resistivity models at selected depth intervals..............14

5. Map showing interpreted elevation of the Muav Limestone-Bright Angel Shale contact derived from smooth and minimum-layer inverted resistivity models, outcrop observations, and well lithologic records ......................................................15

6. Map showing primary interpretation of the elevation of the top of crystalline basement derived from smooth and minimum-layer inverted resistivity models, outcrop observations, well lithologic records, and the gravity-derived depth-to-bedrock model

7. Sections of inverted resistivity models for selected flight lines with interpreted hydrostratigraphic contact elevations including alternative basement elevation scenarios.

8. Maps showing alternative scenarios of the elevation of the top of crystalline basement derived from inverted resistivity models, outcrop observations, well lithologic records, and the gravity-derived depth-to-bedrock model.

\section{Table}

1. Airborne electromagnetic data processing filters and inversion settings 


\section{Conversion Factors}

International System of Units to U.S. customary units

\begin{tabular}{lcc}
\hline \multicolumn{1}{c}{ Multiply } & By & To obtain \\
\hline centimeter $(\mathrm{cm})$ & Length & \\
meter $(\mathrm{m})$ & 0.3937 & inch (in.) \\
kilometer $(\mathrm{km})$ & 3.281 & foot (ft) \\
meter $(\mathrm{m})$ & 0.6214 & mile (mi) \\
& 1.094 & yard (yd) \\
\hline square kilometer $\left(\mathrm{km}^{2}\right)$ & Area & acre \\
square kilometer $\left(\mathrm{km}^{2}\right)$ & 247.1 & square mile $\left(\mathrm{mi}^{2}\right)$ \\
\hline
\end{tabular}

\section{Datum}

Vertical coordinate information is referenced to the North American Vertical Datum of 1988 (NAVD 88).

Horizontal coordinate information is referenced to the North American Datum of 1983 (NAD 83).

Altitude, as used in this report, refers to distance above the land surface.

\section{Abbreviations}

$\begin{array}{ll}\text { AEM } & \text { airborne electromagnetic } \\ \mathrm{A} \mathrm{m}^{2} & \text { ampere square meter } \\ \text { DOI } & \text { depth of investigation } \\ \text { GPS } & \text { Global Positioning System } \\ \mathrm{HM} & \text { high moment } \\ \mathrm{Hz} & \text { hertz } \\ \mathrm{IP} & \text { induced polarization } \\ \text { LCI } & \text { laterally constrained inversion } \\ \text { LM } & \text { low moment } \\ \text { NED } & \text { National Elevation Dataset } \\ \text { ohm-m } & \text { ohm-meter } \\ \text { USGS } & \text { U.S. Geological Survey }\end{array}$




\title{
Major Hydrostratigraphic Contacts of the Truxton Basin and Hualapai Plateau, Northwestern Arizona, Developed from Airborne Electromagnetic Data
}

\author{
By Lyndsay B. Ball
}

\begin{abstract}
The area surrounding the Grand Canyon has spectacular outcrop exposure in the modern canyon walls, leading to stratigraphic contact delineations that are well constrained near canyons yet poorly constrained where the terrain remains undissected and relatively unexplored by boreholes. An airborne electromagnetic and magnetic survey of the western Hualapai Indian Reservation and surrounding areas was undertaken to support the development of a three-dimensional hydrostratigraphic framework of the Truxton basin and Hualapai Plateau. These data were used to develop models of the resistivity structure with total depths of investigation ranging from 200 meters in the most conductive parts of the Truxton basin to more than 600 meters in the higher resistivity areas underlying the Hualapai Plateau. The modeled resistivity structure was used in conjunction with geologic maps, well lithologic records, and results from gravity models of the depth to bedrock to develop high-resolution regional interpretations of the elevation of the Muav Limestone-Bright Angel Shale contact and the top of the crystalline basement. These contacts are conceptualized to serve as the base of the Paleozoic limestone aquifers primarily underlying the Hualapai Plateau and the Tertiary-Quaternary sedimentary and volcanic aquifers of the Truxton basin, respectively.
\end{abstract}

\section{Introduction}

Near the Grand Canyon in northwestern Arizona, the geologic structure defining the regional hydrostratigraphy is well defined in outcrop in the deeply incised canyons but poorly defined where the terrain remains undissected or bedrock is buried by sediments and volcanic deposits. The limited distribution of boreholes and geologic observations across large areas leads to uncertainty in the geometry of hydrostratigraphic units, hindering the development and evaluation of groundwater flow models. As part of a broader study of the groundwater resources of the western Hualapai Indian Reservation (see Mason, Knight, and others, 2020), the U.S. Geological Survey (USGS), in cooperation with the Bureau of Reclamation, has undertaken an airborne electromagnetic (AEM) and magnetic survey of the Hualapai Plateau and Truxton basin. These data have been used to interpret the concealed geologic structure and to refine the regional hydrostratigraphic framework (fig. 1).

The resistivity of geologic materials varies by several orders of magnitude (Palacky, 1988). Electrical current in geologic materials is primarily carried through a combination of electrolytic conduction through pore fluids and surface conduction along grains, and, as such, subsurface bulk resistivity is sensitive to groundwater salinity, volumetric water content, lithologic and mineral composition, and the presence of clay. The greater Grand Canyon area has a broad lithologic range, including alluvial and volcanic deposits, limestone, siltstone, sandstone, shale, and crystalline rocks, leading to a substantial range in resistivity values. Resistivity contrasts can therefore serve as an indicator of the characteristic change in lithologic composition that occurs between some geologic formations and can be used to interpret the contacts between hydrostratigraphic units.

The electromagnetic method is commonly used to estimate resistivity structure. Because electromagnetic instruments are inductive and do not require direct ground contact, these systems can be deployed using a variety of platforms ranging from borehole tools deployed in wells to sensors towed by aircraft. Airborne geophysical surveys, including AEM surveys, allow high-resolution exploration at regional scales and over areas with limited accessibility or difficult terrain that would otherwise be impractical to survey using ground-based geophysics and with the spatial continuity not possible through borehole measurements.

\section{Purpose and Scope}

This work is part of a larger study of the groundwater resources of the western Hualapai Indian Reservation and Truxton basin. The results of this study are presented in five chapters: chapter A provides an overview of the objectives and overall findings of the study, a brief summary of previous USGS investigations of region, and basic hydrogeologic context (Mason, Knight, and others, 2020); chapter B provides an overview of the regional geology and hydrology 


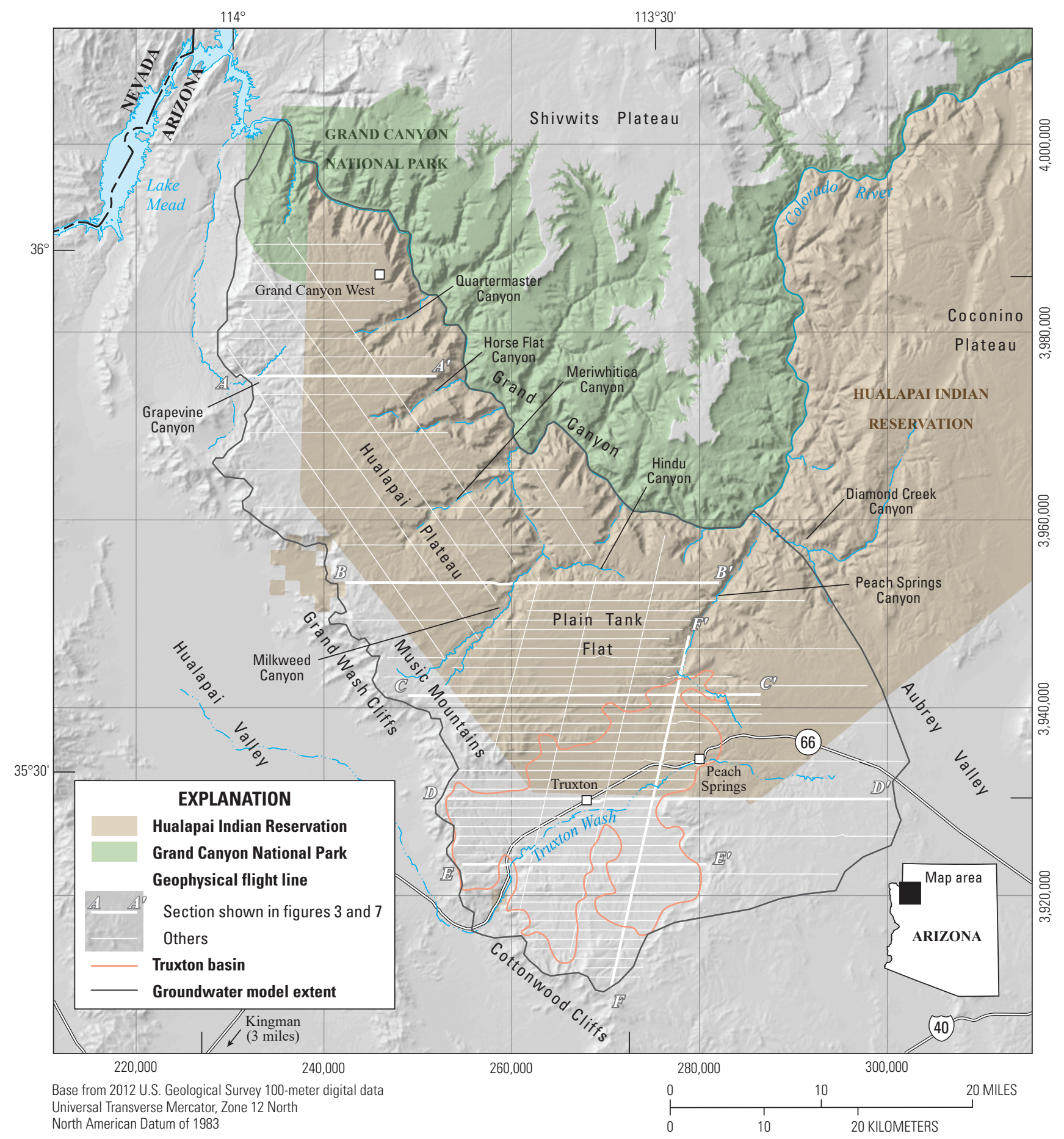

Figure 1. Map of the Grand Canyon West airborne geophysical survey area showing flight lines, the groundwater model extent, the Truxton basin, and major geographic features. Bold flight lines labeled $A-A^{\prime}$ through $F-F^{\prime}$ correspond to sections shown in parts $A-F$ of figures 3 and 7 .

(Mason, Bills, and Macy, 2020); chapter C describes gravity measurements and modeling of the depth to bedrock in the central part of the Truxton basin (Kennedy, 2020); and chapter E discusses the development and results of a groundwater flow model of the Truxton basin (Knight, 2020).

This chapter (chap. D) describes the design and

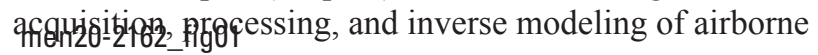

geophysical data acquired in March 2018 over the Truxton basin and Hualapai Plateau. Interpretations of major hydrostratigraphic contacts encompassing the full survey area and pertinent to the groundwater modeling effort are presented and discussed. The airborne geophysical data described in this report are available online at https://doi.org/10.5066/ P91OLJN3 (Ball and others, 2020). 


\section{Survey Area Description}

The airborne geophysical survey covered an area along the south rim of the western Grand Canyon extending from near Lake Mead to the intersection of Peach Springs Canyon with the Colorado River (fig. 1), referred to herein as the Grand Canyon West survey area. The survey encompassed an area of 3,070 square kilometers $\left(\mathrm{km}^{2}\right)$ and included most of the area hydrogeologically upgradient of the Colorado River along the southern side of the reach described above. The region receives relatively low precipitation $(<50$ centimeters per year $[\mathrm{cm} / \mathrm{yr}])$ and high evapotranspiration $(>160 \mathrm{~cm} / \mathrm{yr})$, and there is slightly greater rainfall at higher elevations and greater evapotranspiration potential at lower elevations (Bills and Macy, 2016). Regional aquifers are primarily recharged by precipitation at higher elevations in the western and southern parts of the survey area, and groundwater is conceptualized to generally flow northeast following the regional geologic dip. Modern topography, paleocanyons, and geologic structures may act as local to regional controls on groundwater flow.

The Grand Canyon West survey area includes the Hualapai Plateau and the Truxton basin. The Hualapai Plateau is a high-elevation area south of the Grand Canyon that is dissected by deep northeast-trending canyons extending from the Grand Wash Cliffs in the west to the Aubrey Valley and Coconino Plateau in the east (fig. 1). Sedimentary rocks overlie crystalline basement composed of Proterozoic granite, gneiss, and schist (fig. 2, units $\mathrm{Xg}$ and $\mathrm{Xm}$ ). Most of the plateau's thick (hundreds of meters) sedimentary sequences consist of east-northeast dipping Cambrian to Pennsylvanian rocks, including the Tapeats Sandstone, Bright Angel Shale, Muav Limestone, Temple Butte Formation (primarily dolomite), and Redwall Limestone (fig. 2, unit M€); the undivided Supai Group is present at the surface in the northeastern part of the plateau in places (fig. 2, unit PP) (Richard and others, 2000; Billingsley and others, 2006). The Tonto Group includes the Tapeats Sandstone, Bright Angel Shale, and Muav Limestone, which are the most hydrogeologically significant units and reflect gradational changes in depositional setting. As such, the Tapeats-Bright Angel contact is characterized by interlayered sandstone and shale, which transitions to mostly shale into the Bright Angel. Similarly, the upper parts of the Bright Angel Shale contain numerous limestone layers that transition to predominantly limestone into the Muav (Huntoon, 1977). Tertiary volcanic deposits, primarily basalt and andesite flows and tuffs, are present at the surface in parts of this area, particularly near the Music Mountains (fig. 1; fig. 2, units Tv and Tby). Tertiary-Quaternary deposits are found in the form of semiconsolidated to consolidated alluvial sediments, fine-grained lacustrine deposits, eolian sands, and landslide deposits (fig. 2, units Tso, Tsy, Qo, and Q). These deposits are present in paleocanyons, as surficial deposits, and in modern ephemeral washes (Billingsley and others, 2006).

The Truxton basin is a relatively low-lying area adjacent to the southern part of the Hualapai Plateau, where surface water drains primarily to the southwest towards Hualapai
Valley through Truxton Wash (fig. 1). Several geographic features delineate the margins of the Truxton basin: the Music Mountains to the west, Plain Tank Flat to the north, and the Cottonwood Cliffs to the south and east (fig. 1). In the northeastern part of the Truxton basin, well logs indicate that basin-fill sediments overlie the lower Paleozoic sequence of Muav Limestone, Bright Angel Shale, and Tapeats Sandstone (Mason, Bills, and Macy, 2020). In the rest of the basin, the primary aquifer consists of Paleocene and younger alluvial and lacustrine sediments that are overlying Proterozoic crystalline basement and interbedded with volcanic flows (Billingsley and others, 2006; Bills and Macy, 2016).

Several regional geologic structures are present in the Grand Canyon West survey area (fig. 2). The Hurricane Fault is the largest displacement feature in the area. The fault extends into Utah where stratigraphic separations of more than $2 \mathrm{~km}$ are documented (Stenner and others, 1999; Fenton and others, 2001), and as much as $400 \mathrm{~m}$ of separation has been mapped near Diamond Creek (Billingsley and others, 2006) (figs. 1, 2). This active down-to-the-west normal fault trends north-northeast. The southernmost mapped extent of the fault terminates near the Cottonwood Cliffs (Beard and Lucchitta, 1993). The similarly oriented Toroweap fault is about $10 \mathrm{~km}$ east of the Hurricane Fault and has about 300 m of separation near Diamond Creek (Twenter, 1962). The Meriwhitica fault extends across the Colorado River near Horse Flat Canyon, transitions to a down-to-the-east monocline to the south, and becomes obscured by volcanic deposits near Milkweed Canyon. Horse Flat monocline is mapped about $10 \mathrm{~km}$ west of Meriwhitica monocline and is similarly oriented down to the east. These monoclines and faults may place local to regional controls on groundwater flow as changes in regional dip alter aquifer geometry, aquifers become hydrologically separated or juxtaposed with aquitards, and (or) through enhanced secondary permeability near folds and the possible presence of structurally distinct fault zones that may act as hydrogeologic barriers, conduits, or combined conduit-barriers to flow (Caine and others, 1996).

Paleocanyons related to Paleocene through Eocene erosional stripping of the southwestern Colorado Plateau preserve a northeast-trending paleodrainage system that may place modern controls on groundwater flow (see, for example, Twenter, 1962; Elston and Young, 1991; Young, 2001; Young and Hartman, 2014) (fig. 2). Where buried, these channels are in part responsible for the variable depth to basement and associated aquifer thickness documented in wells (Natural Resource Consulting Engineers, 2011). The paleocanyon sediments consist of locally derived gravel supported by a consolidated to semiconsolidated weathered arkosic matrix interbedded with volcanic deposits (Twenter, 1962; Young, 2001; Billingsley and others, 2006). These sediments have been reported to be in excess of $300 \mathrm{~m}$ thick in Hindu and Milkweed Canyons (Twenter, 1962). Faulting has likely played a role in both the development and modern discontinuity of individual paleocanyons, particularly with respect to channels near the Hurricane Fault (Young, 2001). 


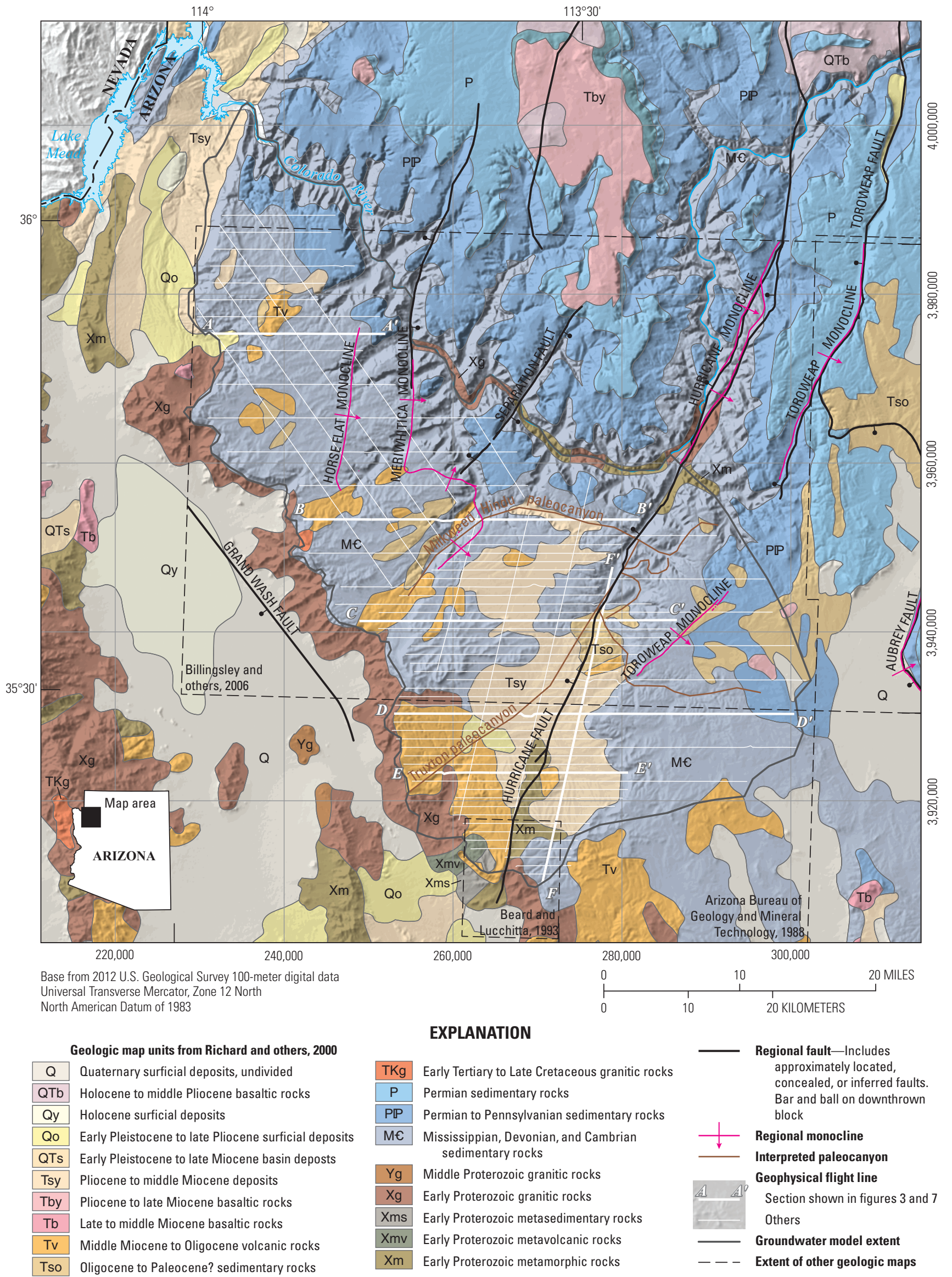


Figure 2 (page 4). Map of the Grand Canyon West airborne geophysical survey area showing flight lines and regional geologic units and structures. Bold flight lines labeled $A-A^{\prime}$ through $F-F^{\prime}$ correspond to sections shown as parts $A-F$ of figures 3 and 7 . Regional faults modified from Arizona Bureau of Geology and Mineral Technology (1988), Beard and Lucchitta (1993), Richards and others (2000), and Billingsley and others (2006); regional monoclines from Billingsley and others (2006); interpreted paleocanyons from Elston and Young (1991).

\section{Methods}

\section{Airborne Geophysical Data Acquisition, Processing, and Inversion}

In March 2018, airborne electromagnetic and magnetic data were acquired by SkyTEM Surveys ApS (Aarhus, Denmark) using the SkyTEM-312 helicopter-borne transient electromagnetic system and a Geometric G822A cesium vapor magnetometer. Transient electromagnetic systems use a pulse of electrical current through a large loop of wire to generate a primary time-varying magnetic field. This primary magnetic field induces electrical current to flow in the subsurface, leading to secondary magnetic fields that vary, in part, as a function of the resistivity structure of the sampled geologic volume. The resulting decay in the secondary magnetic field is measured after the transmitter is turned off in a receiver coil. The SkyTEM-312 AEM system uses dual-moment transmitters housed in a rigid airframe. The high-moment transmitter ( 500,000 ampere square meters $\left.\left[\mathrm{A} \mathrm{m}^{2}\right]\right)$ maximizes the depth of investigation through a multi-turn loop with larger effective transmitter area and higher current; the low-moment transmitter $\left(\sim 4,000 \mathrm{~A} \mathrm{~m}^{2}\right)$ achieves a faster turn-off time by using a lower current and smaller effective transmitter area, allowing early-time data collection and improved sensitivity to shallow resistivity structure (Sørensen and Auken, 2004). Receiver coils rigidly attached near the back of the airframe measure the vertical and horizontal components of the secondary field. Ancillary positional instruments including Global Positioning System (GPS) receivers, laser altimeters, and inclinometers are mounted to the airframe and record the sensor's geographic location, height above ground, and airframe orientation. Detailed specifications of the SkyTEM-312 system deployed during the Grand Canyon West survey are provided in the contractor's report included with the digital data release (Ball and others, 2020).

The airborne geophysical survey consisted of 1,637 line kilometers flown over an area encompassing the groundwater flow model domain (fig. 1; Knight, 2020). The survey was flown with a nominal 4-km flight-line separation over the Hualapai Plateau. A higher resolution 1-km flight-line separation was used over the Truxton basin, the Music Mountains, and Plain Tank Flat where the groundwater modeling effort was expected to require higher resolution information and where targeted hydrostratigraphic contacts were shallower and more likely to be well resolved by the AEM system. The Grand Canyon West survey area presented challenging topography for survey design and data acquisition. In general, the survey altitude was draped to the terrain with a nominal altitude of $35 \mathrm{~m}$; actual sensor altitude averaged $53 \mathrm{~m}$ above land surface with wide variability resulting from the dissected canyon terrain. Owing to aviation safety limitations, flights were not attempted below the canyon rim, resulting in data gaps over many of the deeper side canyons as well as the Grand Canyon itself.

SkyTEM Surveys ApS performed preliminary basic data processing. This processing included merging all sensor data to a uniform 10-hertz $(\mathrm{Hz})$ sampling frequency, tilt correction, and positional shifts to the center of the airframe. Gaps in altimeter and GPS data were linearly interpolated. Magnetic data processing consisted of diurnal corrections using a locally deployed base-station magnetometer, removal of the International Geomagnetic Reference Field, and calculation of the residual magnetic anomaly. Preliminary AEM data processing included primary-field correction to early-time data, normalization for transmitter moment, and adaptive noise filtering. Data acquisition and contractor-performed processing are described in more detail in the supporting documentation and contractor's report available in the digital data release (Ball and others, 2020).

Detailed AEM data processing included additional altimeter processing, manual culling of cultural noise, application of averaging filters to improve signal-to-noise ratios, and removal of low-signal data through a combination of filters and manual culling. Signal strength varies with the geologic structure of the survey area and is notably higher in the Truxton basin and southern Hualapai Plateau where alluvial sediments and shallow shale form relatively conductive terrain. The thick high-resistivity carbonate units underlying much of the Hualapai Plateau result in substantially lower signal-tonoise ratios, particularly in the northernmost part of the survey area where carbonates are thickest. Because of the variability in the AEM data, two different data processing approaches were applied to the data (table 1). The primary "light averaging" processing scheme used a narrow single-break trapezoidal averaging window and was applied across the full survey area. The secondary "heavy averaging" processing scheme used a wider double-break trapezoidal averaging window to boost signal-to-noise ratios. The heavy-averaging scheme was applied to flight lines over the plateau areas where resistive carbonate units are thick and the geologic structure is relatively uniform and flat lying. The objective of applying the heavy-averaging scheme was to maximize the utility of the AEM data for interpreting hydrostratigraphic contacts at depth. In the relatively conductive Truxton basin or in locations where the Bright Angel Shale is within the upper few hundred meters of the land surface, similarly heavy averaging of the AEM data was unnecessary to improve signal-to-noise levels, as signal is naturally higher in these areas and heavy averaging results in a loss of lateral resolution. The primary 
light-averaging scheme is particularly advantageous where the resistivity structure is complex and varies across relatively small distances, such as the near the Hurricane Fault. AEM data from structurally complex areas that have been heavily averaged can be difficult to accurately model and are less useful for geologic interpretation. Data processing procedures are described in more detail in the supporting documentation provided with the digital data release (Ball and others, 2020).

Numerical inverse modeling is used to estimate resistivity structure from AEM data. To meet the objectives of this study (estimation of hydrostratigraphic contacts), deterministic laterally constrained inversions were developed using AarhusINV (Auken and Christiansen, 2004; Auken and others, 2014) implemented in Aarhus Workbench software (Aarhus Geosoftware, Aarhus, Denmark). For the full survey area, "smooth" inverted resistivity models were developed using the lightly averaged data with 32 fixed-depth layers that increase in thickness as the layer interface depth increases from 5 to $700 \mathrm{~m}$. The starting resistivity for all model layers was 300 ohm-meters (ohm-m). Relatively weak lateral (1.6) and vertical (4.0) constraints on resistivity were chosen to allow rapid transitions in resistivity between layers and soundings; weak constraints were considered to be most appropriate for the local geologic structure where abrupt transitions in rock types are common. A cumulative sensitivity-based AEM depth of investigation (DOI) was calculated for each sounding using the approach developed by Christiansen and Auken (2012) and implemented in Aarhus Workbench to determine the depth at which the model transitions from being well constrained by the data to having reduced data sensitivity.

In addition to the fixed-layer smooth models, "minimum layer" models were also developed for the plateau areas using the heavily averaged data to guide the interpretation of the depth to geologic contacts of interest. In contrast to the fixed thickness and depth of layers of the smooth model, the minimum-layer model allows the layer interface depths to vary in addition to resistivity, but for a smaller number of layers. This approach can result in more accurate layer elevations where the simplified minimum-layer model is appropriate to represent the data and local geologic structure, especially at greater depths where the layers of the smooth model are relatively thick. Inversion model parameters were chosen on the basis of iterative tests of multiple parameter combinations, where models were validated by a combination of model misfits to the AEM data and accurate recovery of estimated formation contact elevations extrapolated from outcrop observations. Three-layer models were developed with interfaces at 20 and $300 \mathrm{~m}$ depth as a starting model domain. Layers 1 and 2 have starting resistivities of $1,000 \mathrm{ohm}-\mathrm{m}$ and layer 3 has a starting resistivity of $100 \mathrm{ohm}-\mathrm{m}$, as a proxy for the Paleozoic carbonates overlying the Bright Angel Shale. Lateral constraints were moderately firm (1.2), as the geologic structure of the plateau areas tends to be relatively uniform and flat lying.

Some soundings in the AEM dataset exhibit induced polarization (IP) effects that hinder the development of accurate resistivity models through the inversion approach used here. These effects are caused by a combination of the presence of chargeable materials and the specific resistivity structure. Airborne IP effects can be measurable where chargeable materials, such as metallic minerals, clay, and (or) fine-grained materials are present in the shallow near surface and are directly underlain by highly resistive materials. These effects were observed primarily on the Hualapai Plateau where thin Tertiary-Quaternary alluvium and lower Pennsylvanian-upper

Table 1. Airborne electromagnetic data processing filters and inversion settings

[s, seconds; LM, low moment; HM, high moment; LCI, laterally constrained inversion; na, not applicable. All times are relative to the beginning of the transmitter turn-off]

\begin{tabular}{|c|c|c|c|c|c|c|c|c|}
\hline Processing scheme & $\begin{array}{l}\text { Trapezoidal } \\
\text { averaging } \\
\text { sounding } \\
\text { distance (s) }\end{array}$ & $\begin{array}{c}\text { Transmitter } \\
\text { moment }\end{array}$ & $\begin{array}{c}\text { Receiver } \\
\text { gate time (s) }\end{array}$ & $\begin{array}{l}\text { Window } \\
\text { width (s) }\end{array}$ & Inversion type & $\begin{array}{c}\text { Number } \\
\text { of model } \\
\text { layers }\end{array}$ & $\begin{array}{c}\text { Lateral } \\
\text { constraint }\end{array}$ & $\begin{array}{c}\text { Vertical } \\
\text { constraint }\end{array}$ \\
\hline \multirow[t]{5}{*}{ Heavy averaging } & \multirow[t]{5}{*}{3} & \multirow[t]{2}{*}{ LM } & $1 e^{-5}$ & 8 & \multirow{5}{*}{$\begin{array}{l}\text { Minimum-layer } \\
\text { LCI }\end{array}$} & \multirow[t]{5}{*}{3} & \multirow[t]{5}{*}{1.2} & \multirow[t]{5}{*}{ na } \\
\hline & & & $5 e^{-5}$ & 12 & & & & \\
\hline & & \multirow[t]{3}{*}{ HM } & $1 \mathrm{e}^{-4}$ & 8 & & & & \\
\hline & & & $5 e^{-4}$ & 12 & & & & \\
\hline & & & $1 \mathrm{e}^{-3}$ & 16 & & & & \\
\hline \multirow[t]{4}{*}{ Light averaging } & \multirow[t]{4}{*}{1.5} & LM & $1 e^{-5}$ & 6 & \multirow[t]{4}{*}{ Smooth LCI } & \multirow[t]{4}{*}{32} & \multirow[t]{4}{*}{1.6} & \multirow[t]{4}{*}{4.0} \\
\hline & & & $1 \mathrm{e}^{-4}$ & 8 & & & & \\
\hline & & HM & $1 \mathrm{e}^{-4}$ & 6 & & & & \\
\hline & & & $1 \mathrm{e}^{-3}$ & 8 & & & & \\
\hline
\end{tabular}


Mississippian clastic rocks are present on the surface and underlain by limestone. IP effects were also found in some parts of the Truxton basin where thin alluvial cover overlies resistive crystalline rocks. Where the IP component is a substantial part of the total measured response of the AEM system, the resistivity models derived from the resistivity-only inversion can become inaccurate (Viezzoli and others, 2017). Where IP effects were observed, the entire sounding was removed, resulting in data gaps in areas.

\section{Interpretation Approach}

Two major hydrostratigraphic contacts were delineated using the inverted resistivity models derived from the AEM data: the Muav Limestone-Bright Angel Shale contact and the top of the crystalline basement (herein, basement surface). On the Hualapai Plateau, the Rampart Cave Member of the lower Muav Limestone is conceptualized to be the primary aquifer, with the underlying Bright Angel Shale acting as the aquifer base. This conceptualization has been suggested by numerous previous investigators and is supported by observations of springs along this contact in canyon exposures (see, for example, Twenter, 1962; Huntoon, 1977). In much of the Truxton basin, erosion has removed most or all of the Paleozoic sequence. Subsequent deposition of sediments and volcanic materials in a network of paleocanyons and across the Truxton valley have led to a heterogenous aquifer where the sedimentary and volcanic deposits directly overlie crystalline basement. These paleocanyon and basin-fill deposits are conceptualized as the Truxton aquifer, with the crystalline basement acting as the aquifer base.

Inverted resistivity models serve as the primary foundation of the hydrostratigraphic interpretation. Manual interpretation of the basement surface and the Muav-Bright Angel contact were made by picking the elevation at which the resistivity structure transitions from relatively low resistivity sediments to high-resistivity crystalline rock, or high-resistivity limestone to low-resistivity shale, respectively. The smooth models with fixed layer thicknesses were used independently throughout the Truxton basin and across parts of the Hualapai Plateau where the Muav-Bright Angel contact and the basement surface are relatively shallow $(<300 \mathrm{~m}$ deep) and where the resistivity structure is too complex for the simple minimum-layer models to effectively represent the geology, such as near faults and paleocanyons and in areas with substantial lithologic variability resulting in a variable number of resistivity layers. The resistivity transitions tend to appear gradational in the smooth models, particularly at greater depths, resulting from a combination of large model-layer thicknesses, model regularization, and reduced sensitivity at depth. The gradational nature of the Muav-Bright Angel contact, where shale and limestone are commonly interlayered, likely also contributes to the gradational resistivity signature. The minimum-layer models, where both layer thickness and resistivity are modeled, were used in places to guide the interpretation of contact elevations. Because the depths to individual model layers are determined on the basis of the AEM data and not fixed as they are in the smooth models, they have the freedom to more accurately reflect a discrete contact elevation and can help reduce the ambiguity of interpreting across a gradational resistivity transition, particularly at greater depths. Where smooth and minimum-layer models both perform well, such as near Plain Tank Flat, the Music Mountains, and the southern parts of the Hualapai Plateau where the depth to the Muav-Bright Angel contact is between about 300 and $500 \mathrm{~m}$, both inversion results were used simultaneously to determine the contact elevations. Where the Muav-Bright Angel contact exceeds about $500 \mathrm{~m}$ in depth, such as in the northeastern Hualapai Plateau and near the rim of the Grand Canyon, the elevation of the top of layer 3 in the minimum-layer model was selected where models were laterally consistent and normalized data misfits were less than 1.5. These criteria ensured that the models adequately represent the data where used for interpretation. In these same areas, where the targeted hydrostratigraphic contacts are relatively deep, the basement surface was commonly not resolved below the conductive Bright Angel Shale. In these instances, the interpreted basement surface was draped below the Muav-Bright Angel contact by 125 to $150 \mathrm{~m}$; the distance between the Muav-Bright Angel contact and the basement surface was estimated using a combination of the observed thicknesses of the Bright Angel Shale and Tapeats Sandstone in nearby outcrop (Billingsley and others, 2006) and the interpreted thickness where both contacts were reasonably well resolved in the smooth models.

Independent information about the geologic structure was used to inform the interpretation of the inverted resistivity models. Observations of contact elevations in outcrop and surficial geologic maps (Arizona Bureau of Geology and Mineral Technology, 1988; Beard and Lucchitta, 1993; Billingsley and others, 2006) were used as controls for developing an understanding of the resistivity signature of the target contacts throughout the survey area, as were lithologic descriptions from drillers' logs from the limited available well data (Natural Resource Consulting Engineers, 2011) and the relative trends seen in the residual magnetic field anomaly derived from the magnetic data acquired during the airborne geophysical survey (Ball and others, 2020). A gravity-derived model of the depth to bedrock, described by Kennedy (2020), was also used in the interpretation of the basement surface in places. In the deepest parts of the Truxton basin, the basement is not resolved in the inverted resistivity sections and commonly falls below the AEM DOI. In these locations, the gravity-derived depth to bedrock is used directly to define the basement surface. 


\section{Results and Discussion}

\section{Regional Resistivity Structure}

Resistivity varies by multiple orders of magnitude within the Grand Canyon West survey area with a strong correlation to contacts between geologic formations and associated lithologic changes mapped at the surface and in outcrop. Figure 3 shows inverted resistivity sections from the smooth models for a selection of flight lines highlighting the characteristic resistivity structure of the region. Visualizations of inverted resistivity sections for all flight lines are provided in the digital data release (Ball and others, 2020). Figure 4 shows maps of the inverted resistivity models at depths near 10, 100, 200, and $400 \mathrm{~m}$ below land surface. On the Hualapai Plateau, alluvial cover typically ranges in resistivity from $<100 \mathrm{ohm}-\mathrm{m}$ to $300 \mathrm{ohm}-\mathrm{m}$, where materials with finer grained lithology, greater clay content, and greater water content are likely to be lower in resistivity (fig. 3A, $B, C, D$, unit QT). Mapped surficial volcanic deposits (Billingsley and others, 2006) exhibit similar resistivity values to those seen in the more resistive alluvial deposits, with values commonly between 100 and $300 \mathrm{ohm}-\mathrm{m}$, although resistivity values in excess of 500 ohm-m are observed in places (fig. $3 A, B, C, D$, unit Tv). These deposits are typically thin $(<50 \mathrm{~m})$ and are present at the surface in the plateau areas. A limited part of the eastern survey area overlaps with outcropping Mississippian-Pennsylvanian Supai Group sedimentary units, consisting primarily of sandstone, siltstone, and limestone; these formations are typically observed to be low to moderate in resistivity $(<100$ to $500 \mathrm{ohm}-\mathrm{m}$ ) (fig. $3 D$, unit PM). Most of the plateau area within the AEM DOI, which exceeds $600 \mathrm{~m}$ in places, consists of highly resistive Paleozoic carbonates ( $>1,000 \mathrm{ohm}-\mathrm{m}$ ) (fig. 3 ). Although some distinguishable differences in the resistivity are apparent between the Redwall Limestone, Temple Butte Formation, and Muav Limestone (for example, fig. 3C, $D$; units $\mathrm{Mr}$, Dtb, and $€ \mathrm{~m}$, respectively), particularly where the formations are present in the upper few hundred meters, in general these units cannot be reliably differentiated on the basis of resistivity alone and most commonly are observed as a single high-resistivity unit (for example, fig. $3 A$, units $\mathrm{Mr} /$ $\mathrm{Dtb} / € \mathrm{~m})$. The Bright Angel Shale, with typical resistivity values between 40 and $80 \mathrm{ohm}-\mathrm{m}$, exhibits a notable resistivity contrast to the overlying high-resistivity carbonates (fig. 3). The Bright Angel Shale is resolved in much of the plateau area where the contact is within $500 \mathrm{~m}$ of the surface, such as near the Grand Wash Cliffs and near the Music Mountains and under Plain Tank Flat where the formation tends to be the shallowest (fig. $3 A, B, C$, unit $€ \mathrm{ba}$ ). The thickness of the Bright Angel Shale can be difficult to discern given its relative depth; where relatively shallow ( $<300 \mathrm{~m}$ in depth to the lower contact), the shale appears to be about $100 \mathrm{~m}$ thick based on the transition to the higher resistivity unit at depth, consistent with mapped outcrop observations (Billingsley and others,
2006). Where a transition in resistivity can be resolved below the Bright Angel Shale, the crystalline basement appears as a high-resistivity unit (>500 ohm-m) (fig. 3, unit X); where the basement exceeds about $500 \mathrm{~m}$ in depth, it typically cannot be resolved below the Bright Angel Shale (for example, fig. $3 A$ ). The Tapeats Sandstone, a relatively thin $(<60 \mathrm{~m})$ sandstone and conglomerate that is present in places between the Bright Angel Shale and the basement (Billingsley and others, 2006), crops out in a few locations along flight lines such as in Grapevine Canyon near the Grand Wash Cliffs. In this location, the Tapeats appears as a thin, relatively conductive layer overlying the resistive basement (fig. $3 A$, unit $€ \mathrm{t}$ ) and has a similar resistivity signature to the Bright Angel Shale. The TapeatsBright Angel contact typically is described as gradational (Huntoon, 1977). As such, the shaly upper portions of the Tapeats Sandstone may be similar in resistivity to the sandy lower Bright Angel Shale. Given the thin nature of the Tapeats Sandstone, its typical depth of hundreds of meters under the Hualapai Plateau, and the observed similarity in resistivity to the overlying Bright Angel Shale where observed at the surface, this unit cannot be reliably mapped from the inverted resistivity models.

The most conductive materials underlying the Hualapai Plateau are associated with sediments in buried paleocanyons (fig. $3 B, C$, unit Ts). These sediments are typically $5-30 \mathrm{ohm}-$ $\mathrm{m}$, and in places, the paleocanyon deposits appear to extend more than $200 \mathrm{~m}$ below the modern land surface. The most notable of these paleocanyon features is near the upper reaches of Milkweed Canyon, where resistive volcanic deposits overlie the sediments (fig. 3C). In Hindu Canyon, these sediments are exposed at the surface and are typically modeled around 100 $\mathrm{m}$ in thickness overlying Paleozoic limestone (fig. 3B). These deposits are typically described as predominantly gravel, and the cause of the relatively conductive nature of the sediments is unclear but may be inherited from the weathered arkosic matrix and the presence of clay (Young, 2001; Billingsley and others, 2006). Elevated groundwater salinity has, to my knowledge, not been documented in these deposits; however, if total dissolved-solids concentrations were elevated in these materials, this would be an alternative explanatory factor for their relatively low resistivity.

Most of the Truxton basin is underlain by relatively low resistivity materials $(5-50 \mathrm{ohm}-\mathrm{m})$ similar to those observed in the sediments of the paleocanyons on the Hualapai Plateau (figs. 3, $4 A, B, C$ ). Interlayered with these sediments, dipping moderate-resistivity layers $(50-300 \mathrm{ohm}-\mathrm{m})$ extend into the basin and appear to be discontinuous. Some of these layers terminate against the hanging wall of the Hurricane Fault and other mapped structures; other apparent fault structures of similar orientation displace or alter the thickness of these layers in other locations (figs. $3 C, D, 4 A, B$ ). These layers commonly correlate to volcanic deposits where they extend to the surface or have been encountered in drill holes (Natural Resource Consulting Engineers, 2011) (fig. 3C, unit Tv). Well logs describe sediments directly overlying crystalline basement rocks west of the Hurricane Fault where the 

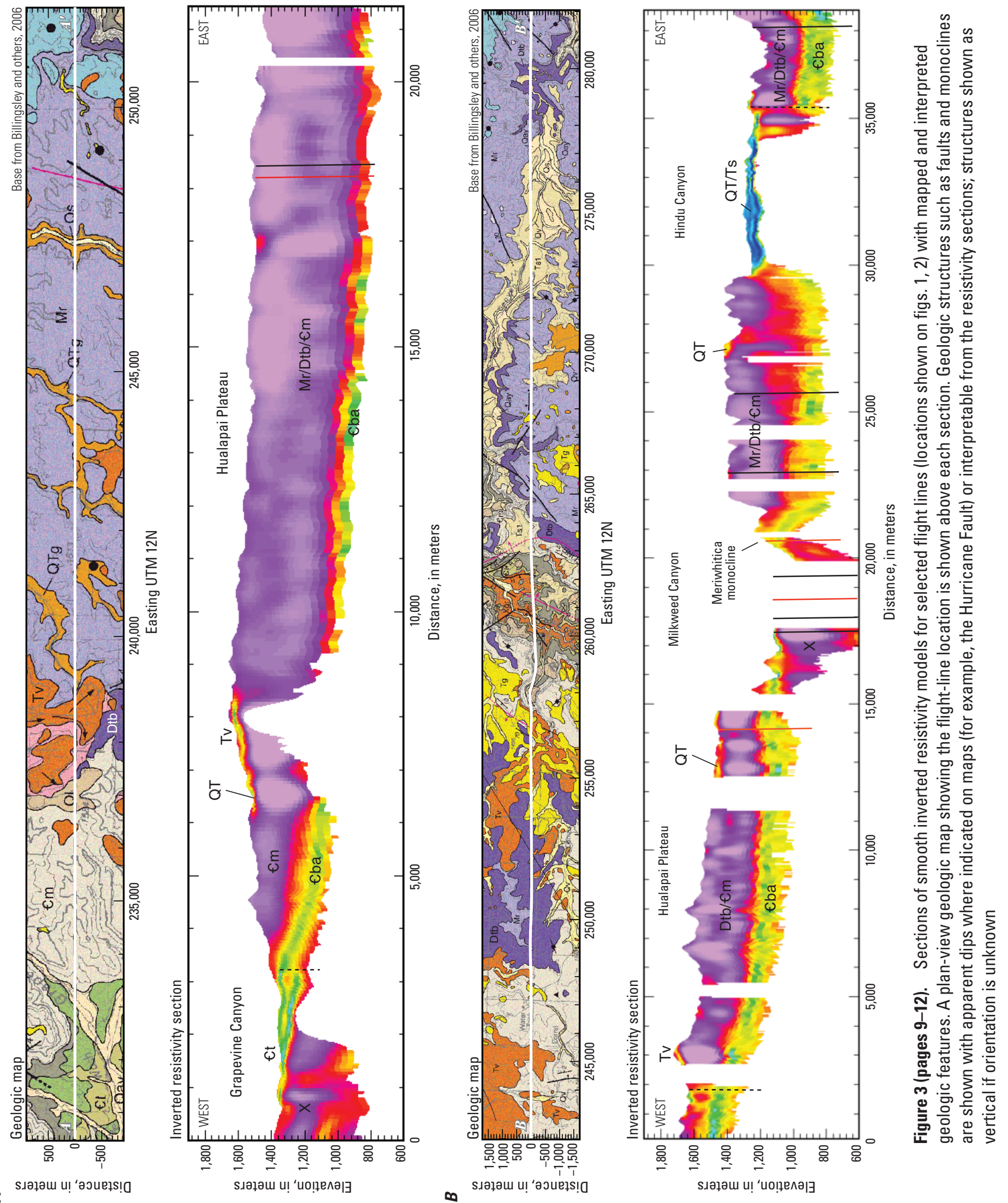

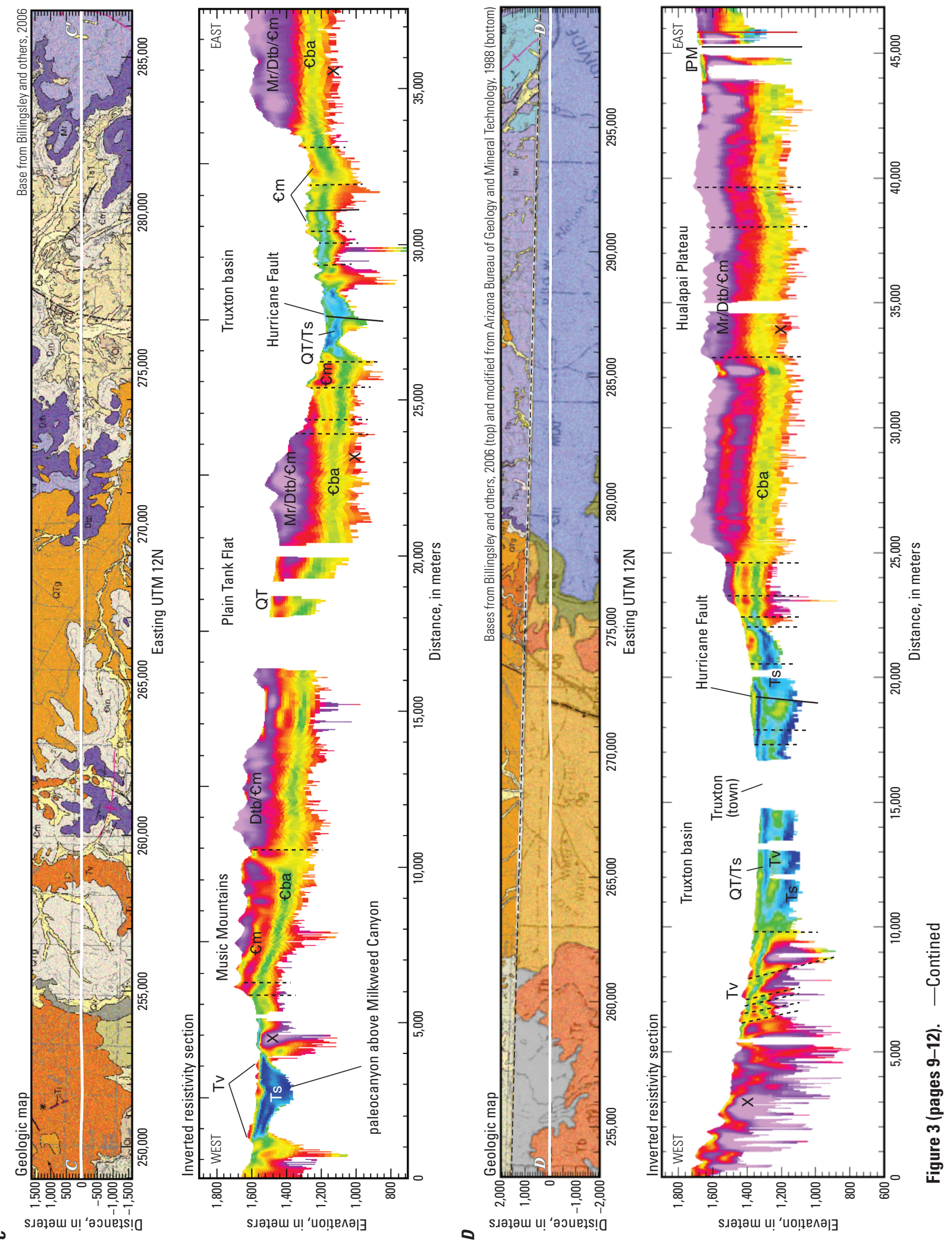


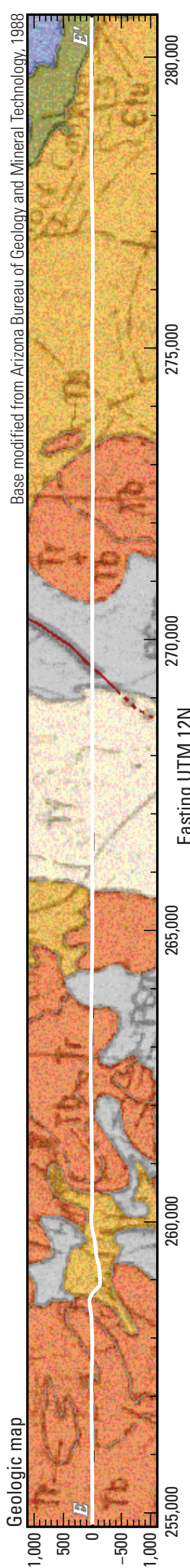

4

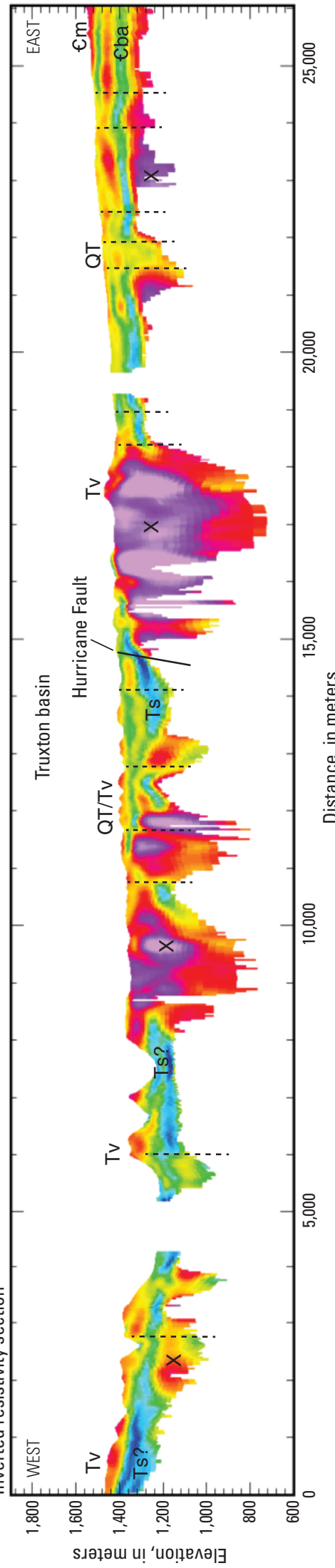

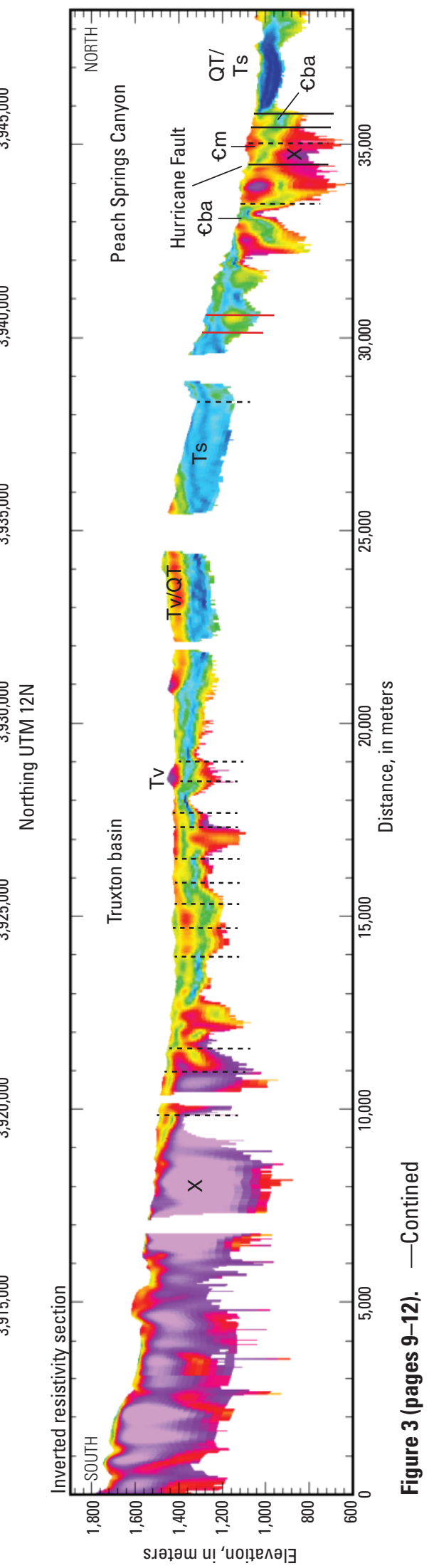



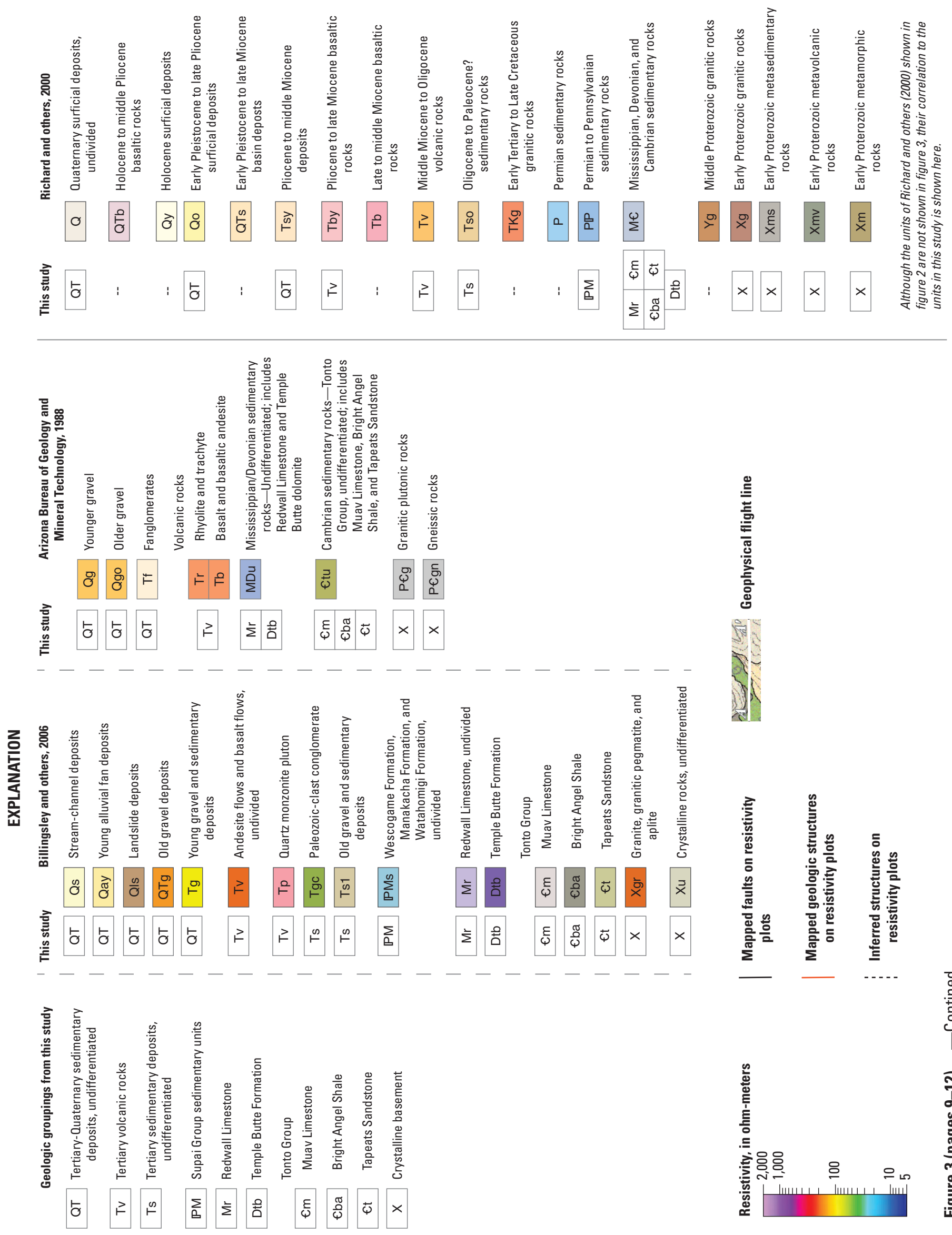

I

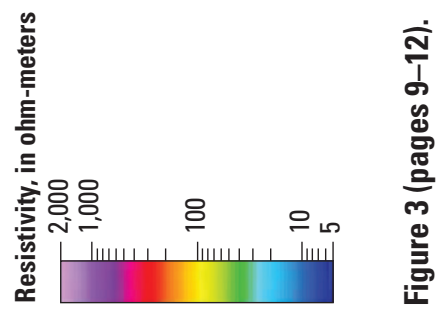


Paleozoic sequence is absent (Natural Resource Consulting Engineers, 2011). East of the Hurricane Fault, Paleozoic rocks may underlie the surficial sediments. Crystalline rocks are exposed at the surface near the southern extent of the basin or underlie thin alluvial cover or remnants of the Bright Angel Shale or Tapeats Sandstone (fig. 3E, unit X). The basement rocks tend to be more resistive ( $>500-1,000 \mathrm{ohm}-\mathrm{m})$ but also have a more complex resistivity character than the more uniformly resistive limestone units, which is not uncommon in metasedimentary and (or) fractured crystalline rock complexes (fig. $3 D$, $E$; fig. $4 B, C, D$, circle 1 ).

The low- and moderate-resistivity sediments of the central part of Truxton basin show a general northeast trend following the previously mapped paleocanyons (fig. 4). These sediments appear to be thickest near the town of Truxton (figs. 3D, 4). A high point in the crystalline basement south of Truxton (fig. $4 B, C$, circle 2) appears to separate this channel into two structural lows. The western low follows the trend of a paleocanyon interpreted by Elston and Young (1991) (fig. $4 B, C$, circle 3 ). The eastern low mostly aligns with the downthrown side of the Hurricane Fault, although the complex geometry of the northern extent of this low suggests that it may have an erosional origin and may also be a paleocanyon (fig. $4 B, C$, circle 4). To the north, as the land surface elevation drops towards the Colorado River, a high-resistivity block correlated to the Paleozoic sequence appears to separate the paleocanyon sediments of the greater Truxton basin from the conductive sediments in lower Peach Springs Canyon (fig. $3 F$, units QT/Ts; fig. 4D, circle 5). This section of the Hurricane Fault is mapped as a relatively complex zone containing several fault strands (Billingsley and others, 2006). Given the relatively high resistivity of both the basement and limestone, the geometric complexity of the faults, and the structural damage zone that may be associated with the fault, it's difficult to accurately interpret the stratigraphy of this region or to assess the hydrologic connectivity of the sedimentary fill of the Truxton basin to lower Peach Springs Canyon.

\section{Delineation of Major Hydrostratigraphic Contacts}

The interpreted hydrostratigraphic contact elevation surfaces are intended to be a regional-scale representation for groundwater modeling of the Paleozoic limestone and Truxton aquifers (figs. 5, 6). As such, these surfaces are not intended to represent internal structure or variations in permeability within individual formations. In many locations, variations in resistivity correlate to internal structure, such as the contrasts between volcanic and sedimentary deposits in the Truxton basin (fig. 3D, E, F, units Tv, Ts, and QT) or layering within the Paleozoic sequence that may indicate changes in porosity, saturation, or lithology (fig. 3C, units $\mathrm{Mr}$ / $\mathrm{Dtb} / € \mathrm{~m})$. The hydrostratigraphic surfaces also do not attempt to explicitly represent individual faults or other geologic structures. Stratigraphic separation along regional structures, such as the Hurricane Fault and Meriwhitica monocline, are apparent in the surfaces (figs. 5-7) where they have substantial influence on the elevation of the hydrostratigraphic contacts. Regional faults in particular appear smoother than typical of planar structures, owing in part to the regional focus of the interpretation, the relatively large distance between flight lines requiring interpolation of contact positions between lines, and the anticipated resolution of the numerical groundwater model (300 m x $300 \mathrm{~m}$ model cells). Smaller faults and monoclines with lower displacements are apparent in many locations in the inverted resistivity models (fig. 3 ) but were not explicitly included in the interpreted hydrostratigraphy owing to its regional-scale focus.

\section{Muav Limestone-Bright Angel Shale Contact}

The elevation of the Muav Limestone-Bright Angel Shale (€m-€ba) contact was delineated as the base of the aquifer for the Paleozoic limestone formations that are present predominantly on the Hualapai Plateau (figs. 5, 7). The inverted resistivity model sensitivity to individual geologic layers varies as a function of the relative depth, thickness, and resistivity contrast of the interlayered units. As such, the relative resistorover-conductor signature of the interpreted Muav-Bright Angel contact reflects the depth of transition from predominantly limestone to predominantly shale and is an aggregated representation of the typically gradational contact between the two formations. Inverted model sections were evaluated in the context of model quality and observations from geologic maps to create a series of interpretational control points defining the three-dimensional (3-D) contact position. Owing to the relatively deep nature of the Muav-Bright Angel contact across the northeastern plateau and the associated low AEM signal-to-noise ratio, the minimum-layer inverted resistivity models were used as the primary resistivity structure guiding interpretation in the northeastern part of the survey area (fig. $7 A, B)$. The top of layer 3 in the minimum-layer models was used as a proxy for contact elevation where the layer interface occurs above the estimated AEM DOI, where normalized model residuals were below 1.5 suggesting that the AEM data could be effectively modeled using this stratigraphic scenario, and where the top of layer 3 could be correlated to the general trend in the elevation of Muav-Bright Angel contact expected from interpolations between outcrop observations in cliff faces and canyons. Where the Muav-Bright Angel contact is within the upper few hundred meters of the land surface and (or) where the resistivity structure showed more complexity than the three-layer scenario, such as near the margins of the Grand Wash Cliffs, near Grapevine Canyon, and near Plain Tank Flat, the smooth models served as the primary interpretation source (fig. 7, all sections).

More than 1,000 Muav-Bright Angel control points were established from the inverted resistivity models. These control points were supplemented with outcrop control points derived from the digitized contact location in the 1:100,000scale Peach Springs quadrangle (Billingsley and others, 


\section{A. 10 meters}

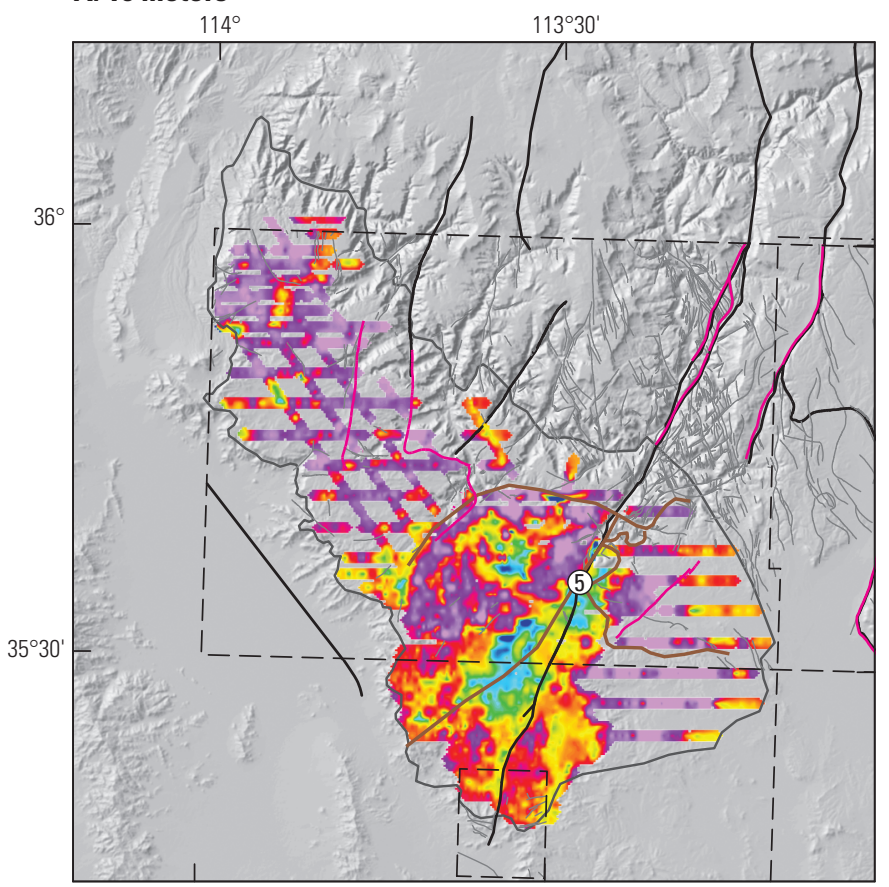

\section{200 meters}

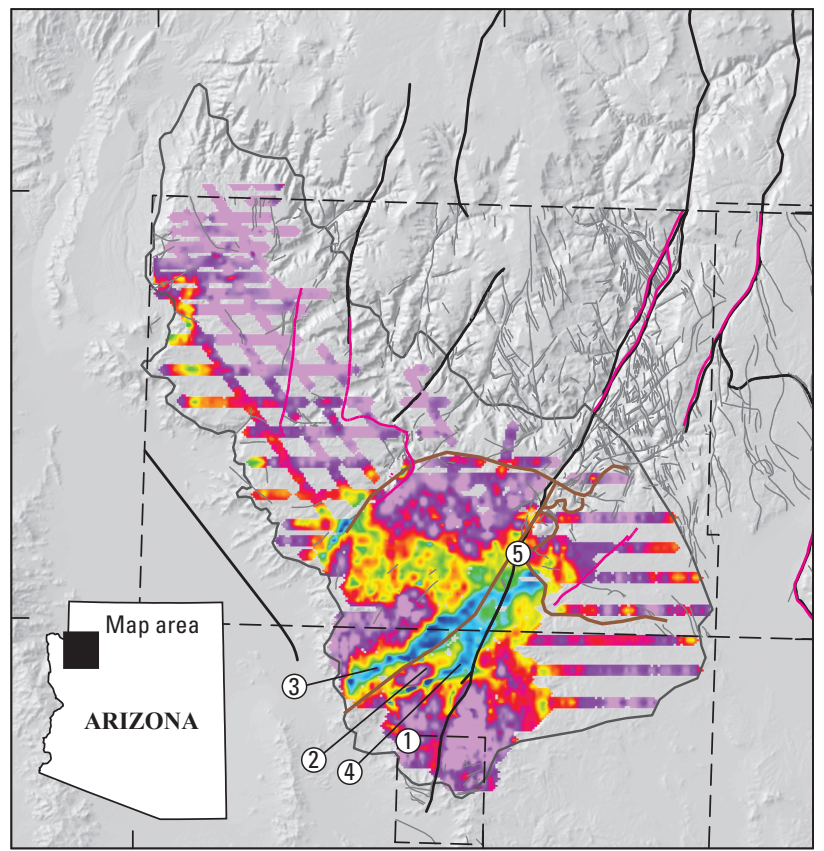

Base from 2012 U.S. Geological Survey 100-meter digital data

Universal Transverse Mercator, Zone 12 North

North American Datum of 1983

\section{EXPLANATION}

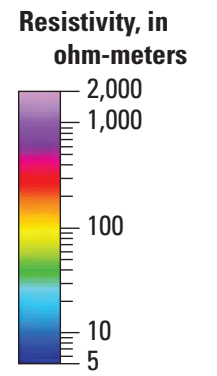

\section{B. 100 meters}

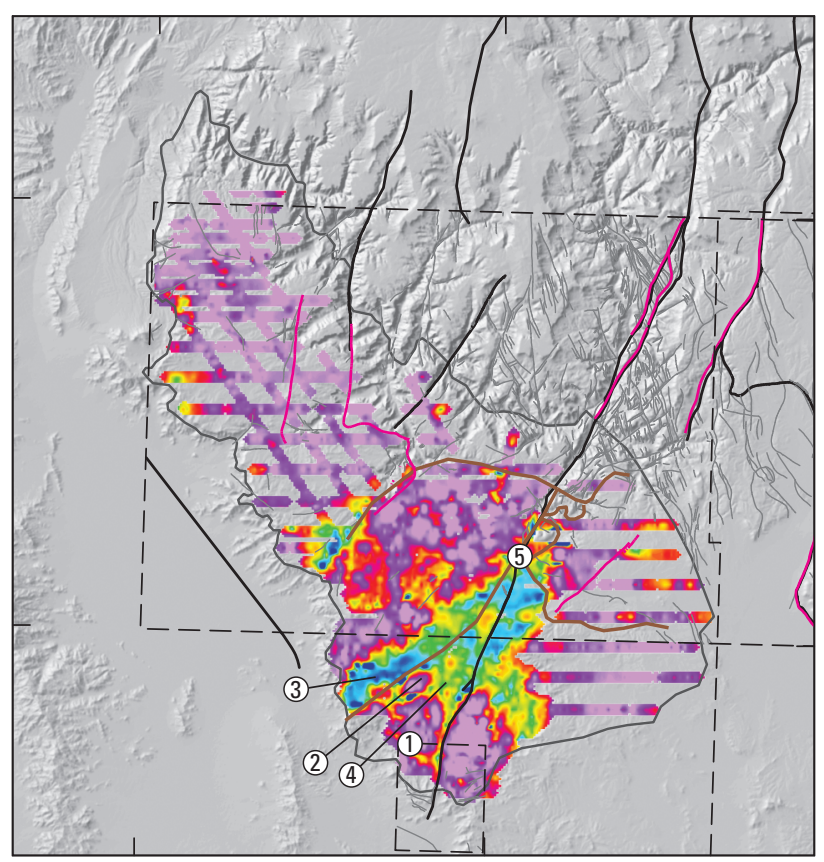

\section{D. $\mathbf{4 0 0}$ meters}

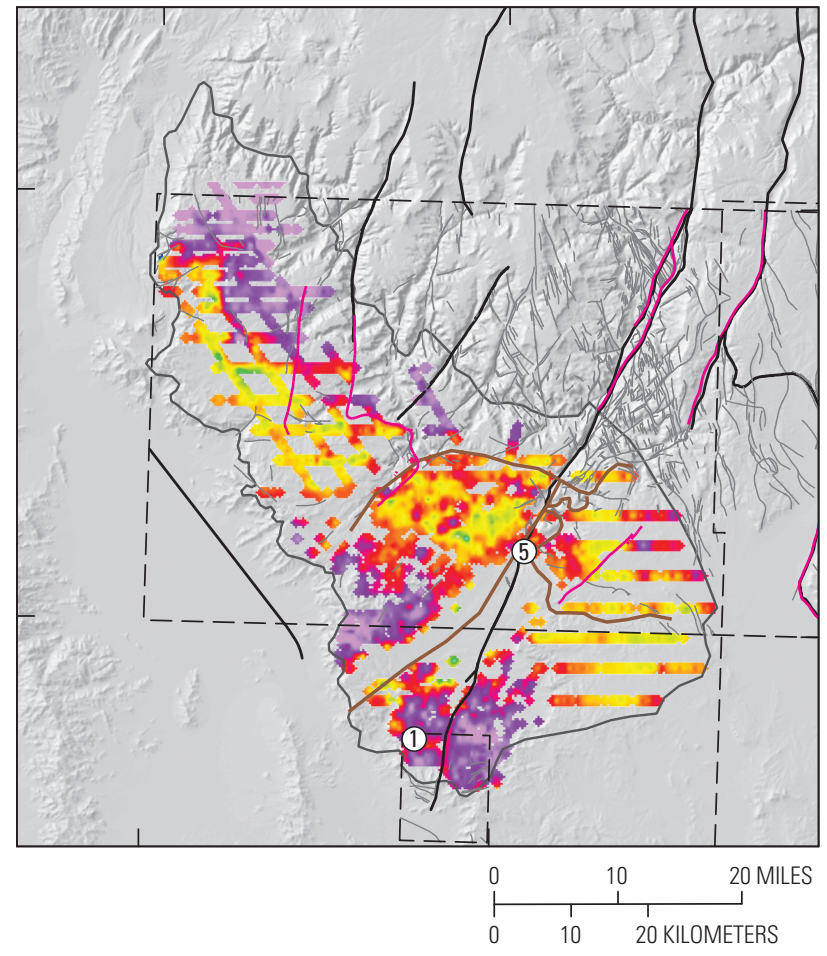

Figure 4. Maps showing smooth inverted resistivity models at depths near $10 \mathrm{~m}(A), 100 \mathrm{~m}(B), 200 \mathrm{~m}(C)$, and $400 \mathrm{~m}(D)$ below land surface. Numbered circles identify features described in the text. See figure 2 for references related to geologic map extents, regional faults, regional monoclines, and interpreted paleocanyons; other mapped faults from Beard and Lucchitta (1993) and Billingsley and others (2006). 
2006). Outcrop elevations were defined by the USGS National Elevation Dataset (NED) 1-arc-second digital elevation model (U.S. Geological Survey, 2016). Control points were gridded into a 3-D surface using the minimum curvature method with a $300-\mathrm{m}$ cell resolution to be consistent with the anticipated resolution of the groundwater model domain. The resulting grid was smoothed to remove interpolation artifacts between control points and to create a geologically realistic surface (fig. 5). The final grid was clipped where its elevation exceeded the NED to accurately represent the modern hydrogeologic discontinuity created by canyons that presently dissect the Hualapai Plateau.

In the Truxton basin and upper Milkweed Canyon, erosion has removed part or all of the Paleozoic sequence including the Muav-Bright Angel contact. In the upper Milkweed paleocanyon, the Bright Angel Shale is interpreted to be absent (fig. 5 , circle 1 ; fig. $7 C$ ). The resistivity underlying the mapped surficial volcanic deposits is notably lower $(<30 \mathrm{ohm}-\mathrm{m})$ than the values typically associated with the Bright Angel Shale ( $40-80 \mathrm{ohm}-\mathrm{m})$ and is more similar in resistivity to the sediments of the Truxton basin described in lithologic records (fig. $3 C$ and $7 C$ ). Because the Muav-Bright
Angel contact is at a higher elevation immediately east of the paleocanyon, the higher resistivity unit underlying the conductive fill of Milkweed Canyon is interpreted to be crystalline basement. The Muav-Bright Angel contact was interrupted at the apparent buried margins of the paleocanyon to reflect the likely erosion of the Paleozoic sequence.

Elston and Young (1991) interpreted an interconnected paleocanyon between modern Milkweed and Hindu Canyons (fig. 5). Although the resistivity underlying both features is low (fig. $7 B, C$ ), modern hydrogeologic connectivity of the Tertiary sediments in a single paleocanyon does not appear likely based on the inverted resistivity models. The deep topographic incision of modern Milkweed Canyon has created a hydrologic disconnect from sediments in Hindu Canyon, suspending them at a modern elevation of about $1,400 \mathrm{~m}$. In modern Hindu Canyon, the transition to higher resistivity materials underlying the conductive sediments is likely to indicate a contact between sediments and limestone, based on the limestone exposed in the canyon walls and the relative elevation of the Muav-Bright Angel contact adjacent to the canyon, and we infer that the Muav-Bright Angel contact remains intact below Hindu Canyon (fig. 7B).

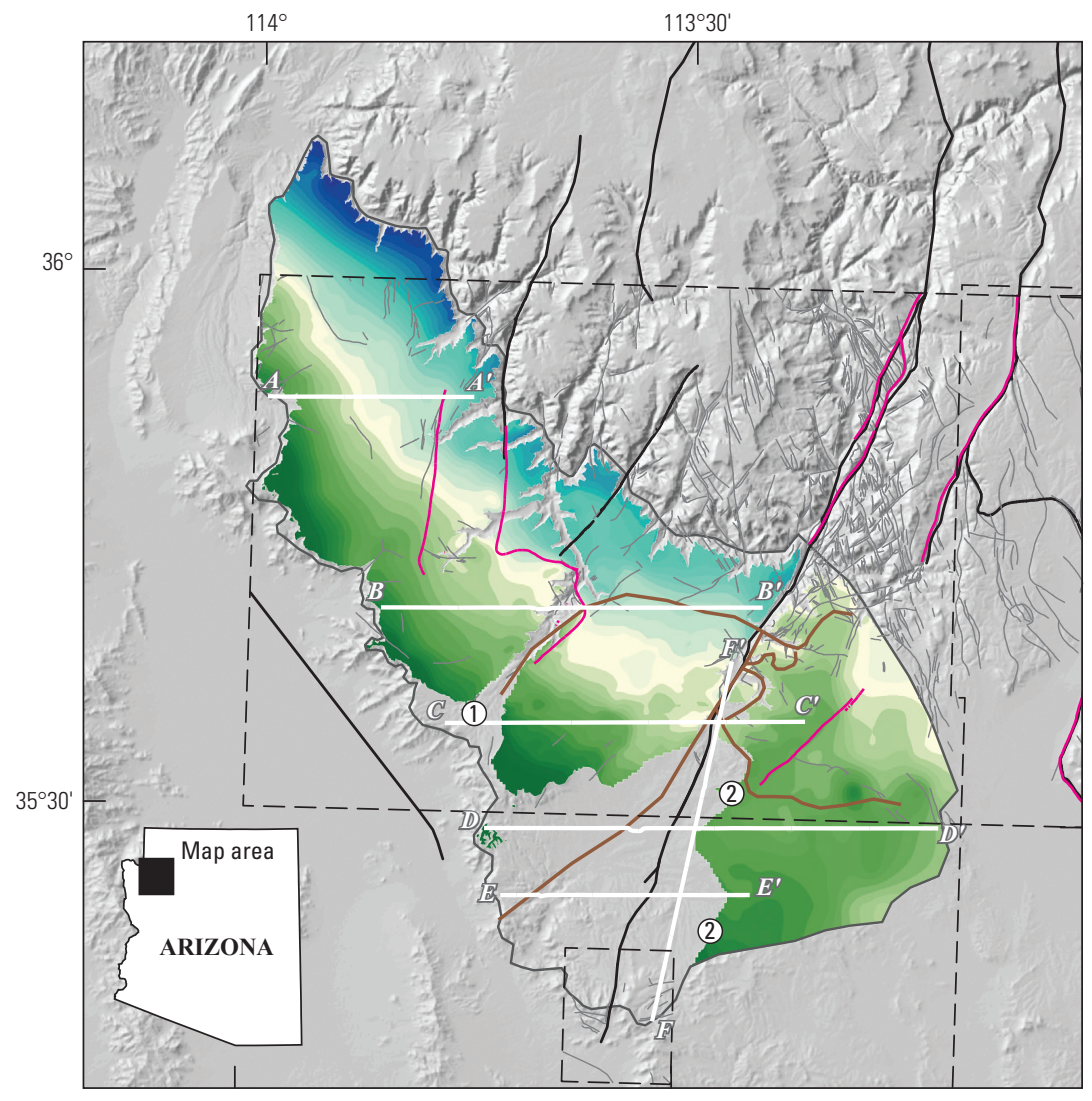

EXPLANATION

Elevation, in meters

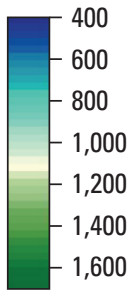

Fault-Includes approximately located, concealed, or inferred faults
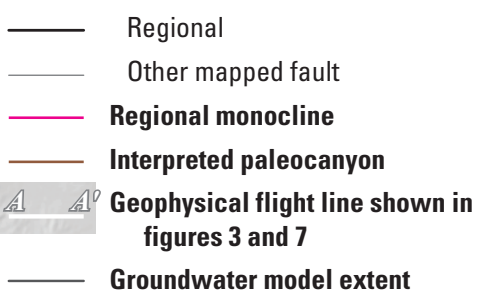

- - - Extent of geologic maps

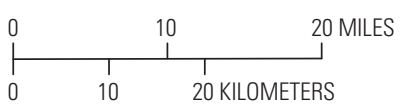

Base from 2012 U.S. Geological Survey 100-meter digital data Universal Transverse Mercator, Zone 12 North

North American Datum of 1983

Figure 5. Map showing interpreted elevation of the Muav Limestone-Bright Angel Shale contact derived from smooth and minimum-layer inverted resistivity models, outcrop observations, and well lithologic records. Airborne geophysical survey flight lines labeled $A-A^{\prime}$ through $F-F^{\prime}$ correspond to parts $A-F$ of figures 3 and 7 . Numbered circles identify features described in the text. See figure 2 for references related to geologic map extents, regional faults, regional monoclines, and interpreted paleocanyons; other mapped faults from Beard and Lucchitta (1993) and Billingsley and others (2006). 


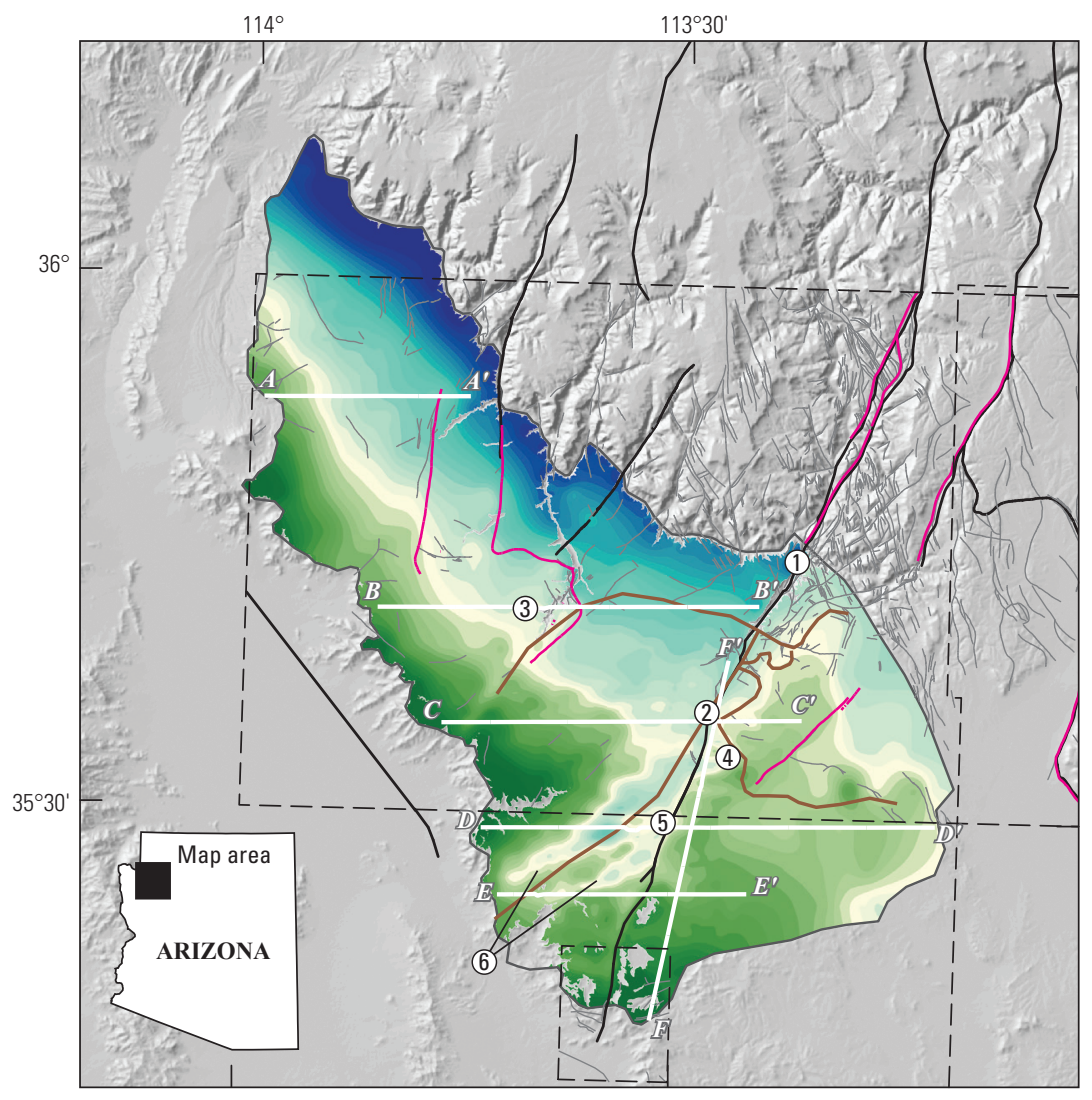

EXPLANATION
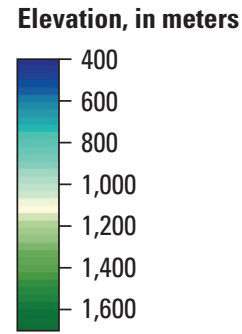

Fault-Includes approximately located, concealed, or inferred faults
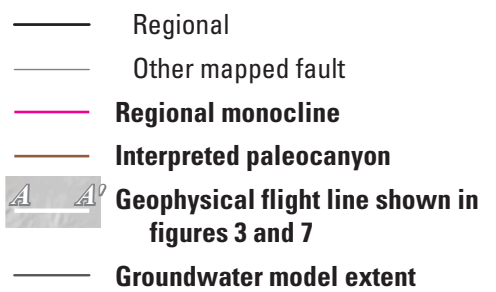

- _ - Extent of geologic maps

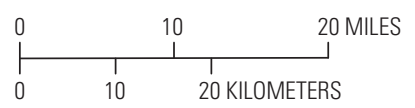

Base from 2012 U.S. Geological Survey 100-meter digital data Universal Transverse Mercator, Zone 12 North North American Datum of 1983

Figure 6. Map showing primary interpretation of the elevation of the top of crystalline basement derived from smooth and minimum-layer inverted resistivity models, outcrop observations, well lithologic records, and the gravity-derived depth-to-bedrock model (Kennedy, 2020). Airborne geophysical flight lines labeled $A-A^{\prime}$ through $F-F^{\prime}$ correspond to parts $A-F$ of figures 3 and 7 . Numbered circles identify features described in the text. See figure 2 for references related to geologic map extents, regional faults, regional monoclines, and interpreted paleocanyons; other mapped faults from Beard and Lucchitta (1993) and Billingsley and others (2006).

The modern extent of the Muav-Bright Angel contact into the Truxton basin is difficult to determine because the contact elevation is generally near or below the land surface at the basin perimeter. The general change in character of the layering of the resistivity structure and mapped surficial geology were used to interpret the Muav-Bright Angel erosional margin in the Truxton basin. In the northern part of the basin in Peach Springs Canyon (fig. 1), the Paleozoic sequence appears in places in surface geologic maps leading to more clearly defined contact margins than farther south. Along several flight lines, the margin is interpreted as the lateral transition from moderately low resistivity values typical of the Bright Angel Shale to lower resistivity values associated with Tertiary sediments (fig. $7 C, D, E, F$ ), consistent with the criteria used to define the interruption of the Muav-Bright Angel contact in upper Milkweed Canyon. This lateral transition in resistivity commonly correlates to a change in layer orientation that may indicate a transition from faulted, dipping Paleozoic rocks to more recent sedimentary deposition. Higher resistivity, gently dipping surficial layers, interpreted as volcanic deposits and Quaternary-Tertiary sediment (fig. 3C, D, E, F, units Tv and QT), also commonly mantle this margin and create interlayered units dipping into the basin that are inconsistent with the limestone-over-shale scenario defining the MuavBright Angel contact. Bright Angel Shale and (or) Tapeats Sandstone could underlie the surficial sediments east of the Hurricane Fault and west of the Muav-Bright Angel contact perimeter and may appear similar in resistivity to the Tertiary sediments. The eastern margin of the Muav-Bright Angel contact, as interpreted, has a stepped appearance that shares some similarity to the mapped edges of paleocanyons and the geometry of modern Peach Springs Canyon. The orientation of these steps is also somewhat similar to the Hurricane and Toroweap faults (fig. 5, circle 2).

The general character of the interpreted Muav-Bright Angel contact (fig. 5) closely follows the mapped regional geologic structure (figs. 2, 5, 7). The contact orientation changes from dipping northeast in the northern Hualapai Plateau, to dipping more north-northeast across the Meriwhitica monocline, and dipping northeast again across the Hurricane Fault. Elevation changes in the Muav-Bright Angel contact across regional faults and monoclines are clearly visible, most notably across the Hurricane Fault and Meriwhitica monocline (figs. 5, 7). More subtle but still-distinctive elevation changes are seen across the Toroweap and Horse Flat monoclines, as are subtle transitions across numerous subregional faults (fig 5, light gray lines) and other structures. 

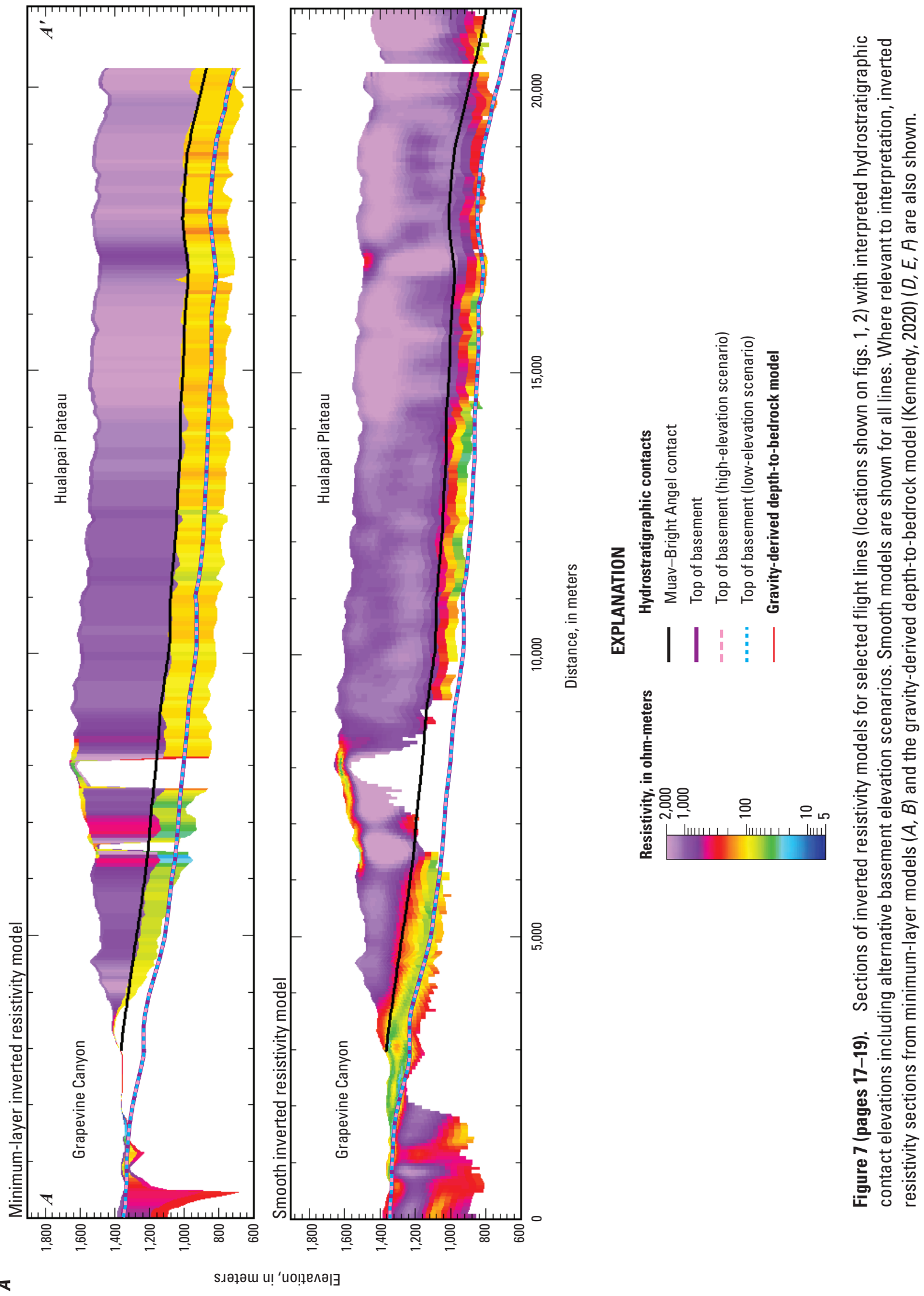

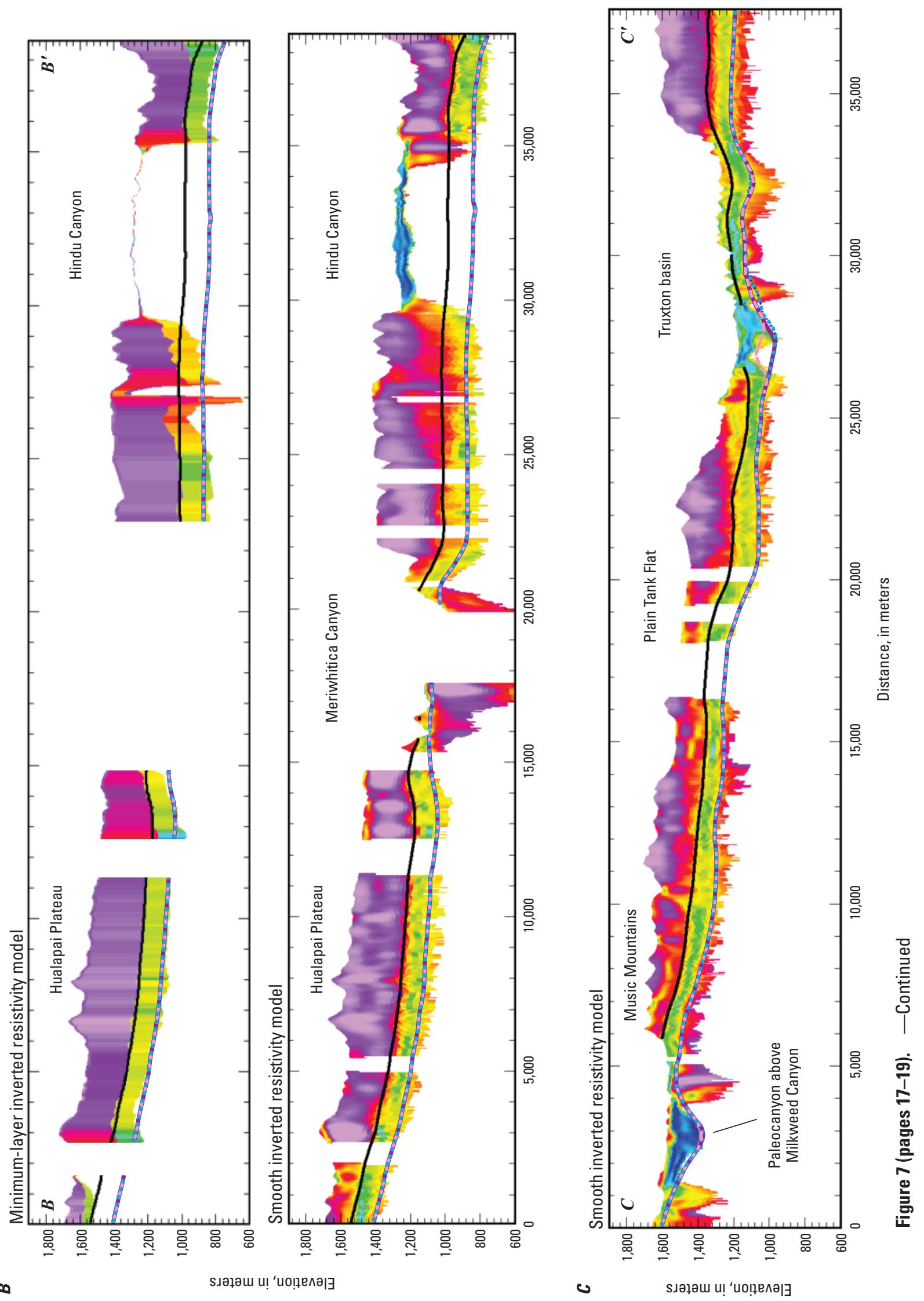

$\infty$

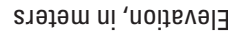




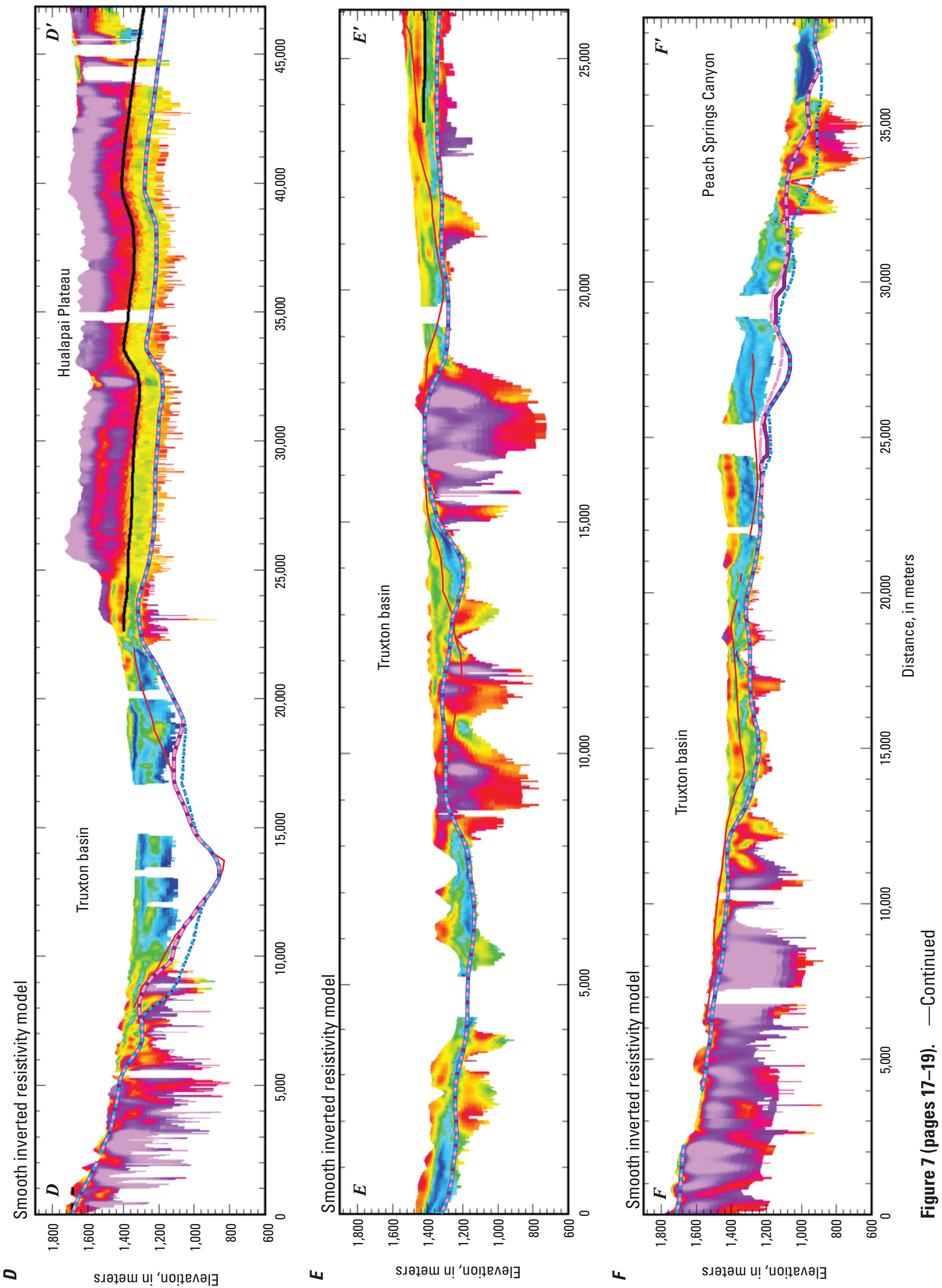




\section{Top of Crystalline Basement}

Within the Truxton basin, the top of the crystalline basement was delineated as a proxy for the base of the sedimentary Truxton aquifer. This surface was interpreted across the Grand Canyon West survey area for stratigraphic continuity. Interpretational control points were created where the inverted resistivity models transition from relatively low resistivity basin-fill sediments or Bright Angel Shale $(<100 \mathrm{ohm}-\mathrm{m})$ to relatively high resistivity basement rocks $(>500 \mathrm{ohm}-\mathrm{m})$. In the deepest parts of the Truxton basin, the generally low resistivity and relative thickness of the sediment leads to an AEM DOI that does not fully capture the basement contact. Although the AEM data can be used to constrain a minimum thickness of the sedimentary fill, in the deepest parts of the basin the gravity-derived depth-to-bedrock model was used as a guide to define the total depth of the basin below the AEM DOI (Kennedy, 2020) (fig. 7D, E). Under the northern part of the Hualapai Plateau where minimum-layer inverted resistivity models were used to interpret the Muav-Bright Angel contact, the basement is not resolved. In these locations, the basement surface was draped 125 to $150 \mathrm{~m}$ below the elevation of the Muav-Bright Angel contact. The AEM-derived control points were supplemented with outcrop contact elevations, gridded, smoothed, and intersected with the NED using the same process that was used to develop the Muav-Bright Angel contact.

In some locations, the gravity-derived depth-to-bedrock models are inconsistent with the resistivity structure indicative of the basement surface. In places, the gravity model predicts the depth to bedrock as well within the stratified and low-resistivity structure of the inverted resistivity sections (fig $7 D, E, F$, gravity model shown as thin red line). The gravity-derived depth to bedrock is not intended to be conceptually identical to the top of the crystalline basement. The gravity model is conceptually representative of a density contrast between unlithified sediments and rock and could represent sediment overlying sandstone, shale, limestone, siltstone, or crystalline rock. The interpretation of the basement surface is defined by the transition from sedimentary and volcanic units to high-resistivity, low-permeability crystalline rocks. Given the single-density foundation of the gravity model and the uneven distribution of gravity stations, it is possible that these discrepancies between the AEM and gravity models are the result of a multi-layered density structure, where some of the deeper parts of the sedimentary structure create a prominent density contrast to the overlying sediments and are modeled above the crystalline basement contact. The gravity model does commonly coincide with resistivity layers internal to the sedimentary basin fill, such as near the eastern margin of the basin adjacent to the Hurricane Fault (fig. $3 D$,
$E$; fig $7 D, E$ ) and may indicate a transition to a more lithified or denser sedimentary unit. It is also possible that the presence of volcanic deposits within the sedimentary section create density contrasts that affect the gravity model. These deposits are commonly indicated in well lithologic records (Natural Resource Consulting Engineers, 2011) and seen as moderateto high-resistivity layers interlayered in the basin sediments (fig. 3D, $E, F$, unit Tv). Furthermore, gravity station density, and therefore model sensitivity, is not constant throughout the basin (Kennedy, 2020), and the gravity model accuracy may vary throughout the basin. In general, the inverted resistivity models were given precedence when both models were not in agreement.

The general character of the interpreted basement surface under the Hualapai Plateau closely follows the regional structure indicated from geologic maps and observed in the interpreted Muav-Bright Angel contact (figs. 5, 6, 7). The regional mapped faults and monocline structures result in elevation changes in the basement surface. The Hurricane Fault is the highest displacement feature in the survey area, where apparent stratigraphic separations of more than $300 \mathrm{~m}$ are seen across lower Peach Springs Canyon and are likely accommodated by the Hurricane Fault and other closely located structures (fig. 6, circle 1). This separation decreases to $100 \mathrm{~m}$ near upper Peach Springs Canyon (fig. 6, circle 2), and although difficult to track through the sedimentary fill, the fault likely continues through the southern boundary of the Truxton basin. The Meriwhitica monocline is also clearly resolved as a relative high point in the basement collocated to the mapped structure (fig. 6, circle 3; fig. 7B). Smaller mapped faults and monoclines underlying the Hualapai Plateau are also resolved, and similar localized changes in basement elevation can be used to infer several similarly oriented structures.

The depth of the crystalline basement surface in the Truxton basin, and thus the implied sedimentary thickness, is primarily characterized by paleocanyon geometry and buried erosional surfaces (figs. 4, 6). The shape and depth of the Truxton basin appear to be inherited, at least in part, from previously interpreted paleocanyons (Elston and Young, 1991), although these paleocanyons appear to have more complex geometry than previously interpreted. In the lower basin, where paleocanyon deposits have some exposure at the surface, the Truxton paleocanyon has several sinuous channels preserved on the eastern side of the Hurricane Fault. The geometry of these channels is reflected by depressions in the basement surface. Similar sinuous depressions in the basement surface suggest that at least one additional meander may exist in the paleocanyon before it forks into its upper tributaries (fig. 6, circle 4). The Truxton paleocanyon appears to follow the Hurricane Fault in places, where thicker sedimentary deposits are present 
on the western downthrown side of the fault. This is consistent with the implied structural control on the location of the channel previously described by Young (2001) (fig. 6, circle 5). Instead of a single channel, the Truxton paleocanyon appears to split into two tributaries surrounding a basement high that can be observed in the surface geology in places (Arizona Bureau of Geology and Mineral Technology, 1988; Richard and others, 2000) (fig. 3D, E; fig. 6, circle 6; fig. 7D, E). The 1:250,000-scale geologic mapping available in this area suggests that volcanic rocks lie directly on crystalline rock in the southern part of the Truxton basin (Arizona Bureau of Geology and Mineral Technology, 1988). However, the relatively low resistivity of the material overlying the interpreted basement surface and the layered structure is most consistent with sediments infilling the paleotopography underlying the volcanic flows, and these sediments appear similar in composition to those seen farther to the north.

\section{Interpretational Uncertainty and Alternative Structural Scenarios}

The interpretation of major hydrostratigraphic contacts was based on the modeled resistivity structure, which relies on relations between resistivity and local lithology and the interpreter's understanding of the regional geology. For example, in the northern part of the Truxton basin near the top of Peach Springs Canyon, where the base of Paleozoic sequence remains intact but thin, the mix of collocated shallow limestone, shallow crystalline rock, and complex deformation mapped in this section of the Hurricane Fault zone makes definitive interpretation of the basement elevation difficult (figs. $3 F, 6 F$ ). Alternate reasonable geophysical interpretations of this region are possible. One such scenario is where the Paleozoic sequence is thin to absent and a high-resistivity crystalline basement high is juxtaposed against the sedimentary fill following the axes of folds similar to those mapped nearby (fig. $3 F$, red vertical lines), leading to relatively limited hydrogeologic connectivity between the sediments of the main Truxton basin and those in Peach Springs Canyon. Alternatively, the basement could be lower and the high-resistivity region could consist of fractured limestone that also shares the relatively high resistivity values of the crystalline rocks, leading to more likely hydrogeologic connectivity through a fractured carbonate aquifer following the fault damage zone. Alternative interpretations could be proposed for other parts of the basin margin where limestone or volcanic deposits may be present and confused with crystalline rock or where the basement surface falls below the AEM DOI.

To assess structural uncertainty and the potential hydrogeologic implications of non-uniqueness in the interpretation of the basement surface to groundwater simulations of the Truxton aquifer, two alternative scenarios for the elevation of the top of the crystalline basement were developed. The first scenario represents a relatively high basement surface elevation (figs. 7, 8A). The high-elevation basement scenario effectively disconnects the Truxton basin from lower Peach Springs Canyon through a basement high and has a relatively narrow interpretation of the buried paleocanyons (figs. $7 F, 8 A$ ). It also typically uses the AEM DOI as a representation of minimum sedimentary thickness unless compelling evidence from the gravity model or boreholes suggests a deeper interpretation is required. The second scenario represents a relatively low basement surface elevation based on the inverted resistivity models (figs. 7, 8B). In the low-elevation basement scenario, the top of the basement represents a broader erosional surface where the paleocanyons are less distinct. The basement near the top of Peach Springs Canyon is lower in this scenario, effectively allowing connectivity between the sedimentary fill though a damaged Paleozoic sequence in the Hurricane Fault zone to lower Peach Springs Canyon. All three representations of the basement surfaces, the primary interpretation (fig. 5) and the above alternative structural scenarios (fig. 8), were included in groundwater model simulations of the Truxton aquifer, described by Knight (2020). 


\section{A. High-elevation basement scenario}

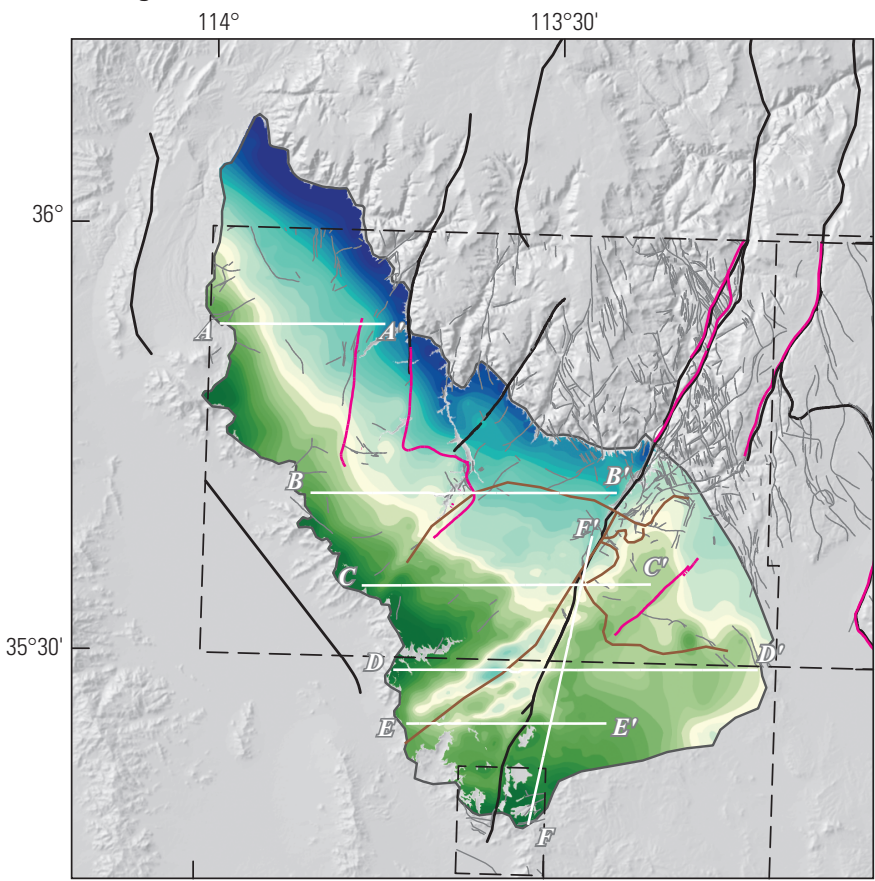

\section{Elevation difference}

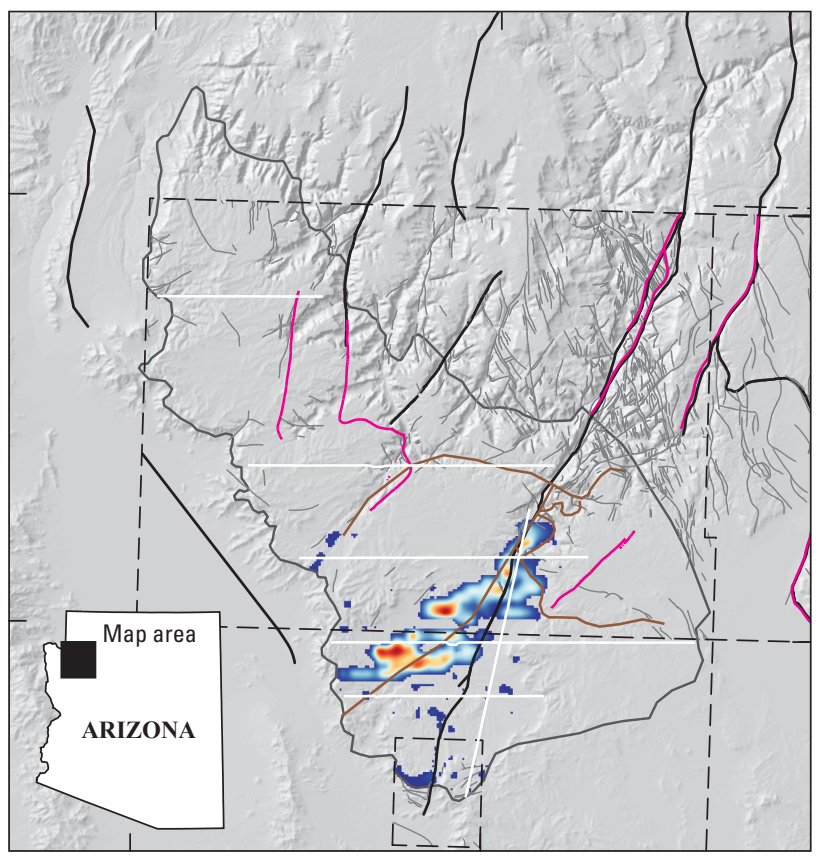

Base from 2012 U.S. Geological Survey 100-meter digital data Universal Transverse Mercator, Zone 12 North

North American Datum of 1983

\section{B. Low-elevation basement scenario}

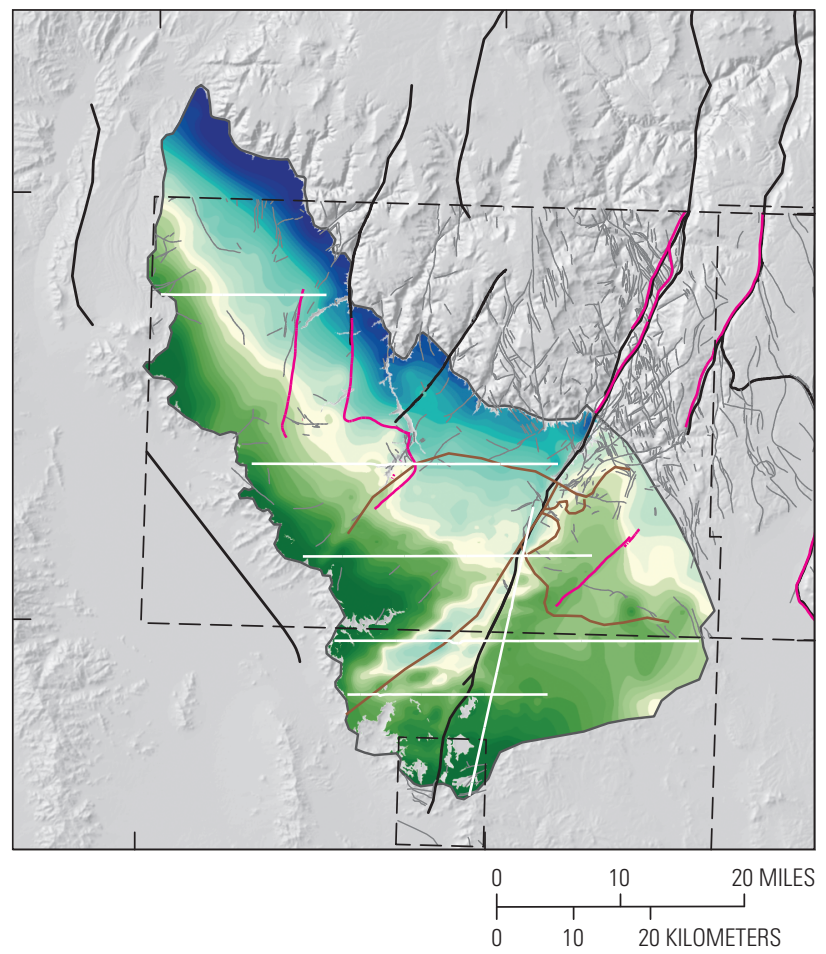

EXPLANATION

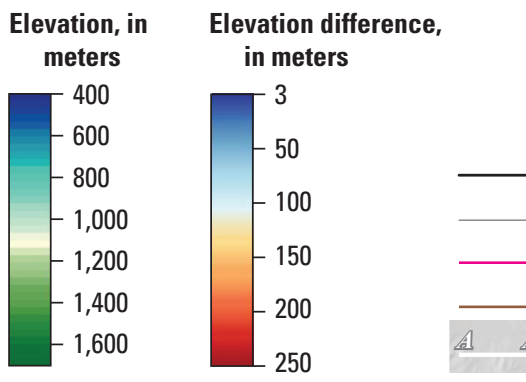

Fault-Includes approximately located, concealed, or inferred faults

Regional

Other mapped fault

Regional monocline Interpreted paleocanyon

Geophysical flight line shown in figures 3 and 7

Groundwater model extent

- - - Extent of geologic maps

Figure 8. Maps showing alternative scenarios of the elevation of the top of crystalline basement derived from inverted resistivity models, outcrop observations, well lithologic records, and the gravity-derived depth-to-bedrock model (Kennedy, 2020). $A$, highelevation basement scenario. $B$, Low-elevation basement scenario. $C$, Elevation difference between scenario surfaces $A$ and $B$. Airborne geophysical survey flight lines labeled $A-A^{\prime}$ through $F-F^{\prime}$ correspond to parts $A-F$ of figures 3 and 7 . See figure 2 for references related to geologic map extents, regional faults, regional monoclines, and interpreted paleocanyons; other mapped faults from Beard and Lucchitta (1993) and Billingsley and others (2006). 


\section{Conclusions}

An airborne electromagnetic (AEM) and magnetic survey of the western Hualapai Indian Reservation and surrounding area was conducted in 2018 to support the refinement of the hydrogeologic framework of the Truxton basin and Hualapai Plateau. These data were used to develop inverted models of the resistivity structure with total depths of investigation ranging from $200 \mathrm{~m}$ in the most conductive parts of the Truxton basin to more than $600 \mathrm{~m}$ in the higher resistivity areas underlying the Hualapai Plateau. Because of the wide range of resistivity values attributed to the local geology, the dramatic terrain leading to large variability in the depth to stratigraphic contacts of interest, and the associated changes in signal strength, AEM data were processed and modeled using a combination of lightly averaging data with fixed-depth-layer smooth models and heavily averaging data with free-depth minimum-layer models. These AEM-derived inverted resistivity models were used in conjunction with geologic maps and well lithologic records to develop interpretations of the elevation of the Muav Limestone-Bright Angel Shale contact and the top of the crystalline basement; the basement interpretation was supplemented by depth-to-bedrock gravity models. These contacts are conceptualized as the base of the Paleozoic limestone aquifer underlying the Hualapai Plateau and the sedimentary and volcanic aquifer of the Truxton basin, respectively. Alternative scenarios for the elevation of the crystalline basement in the Truxton basin were developed that allow groundwater models to explore the hydrogeologic significance of interpretational non-uniqueness inherent to geologic interpretations of geophysical models. The interpreted hydrostratigraphic surfaces capture regional-scale geologic features from geologic maps, including large changes in stratigraphic separation across the Hurricane Fault and other geologic structures in the region, and indicate a number of apparent structures implied from the inverted resistivity models.

\section{References Cited}

Arizona Bureau of Geology and Mineral Technology, 1988, Geologic map of Santa Fe Railroad Company mineral holdings in northwestern Arizona: Arizona Bureau of Geology and Mineral Technology Miscellaneous Map MM-88A, scale 1:250,000.

Auken, E., and Christiansen, A.V., 2004, Layered and laterally constrained 2D inversion of resistivity data: Geophysics, v. 69, no. 3, p. 752-61, https://doi.org/10.1190/1.1759461.

Auken, E., Christiansen, A.V., Kirkegaard, C., Fiandaca, G., Schamper, C., Behroozmand, A.A., Binley, A., Nielsen, E., Effersø, F., Christensen, N.B., Sørenson, K., Foged, N., and Vignoli, G., 2014, An overview of a highly versatile forward and stable inverse algorithm for airborne, groundbased and borehole electromagnetic and electric data: Exploration Geophysics, v. 46, no. 3, p. 223-235, https:// doi.org/10.1071/EG13097.
Ball, L.B., Bills, D.J., and Macy, J.P., 2020, Airborne electromagnetic and magnetic survey data from the western Hualapai Indian Reservation near Grand Canyon West and Peach Springs, Arizona, 2018: U.S. Geological Survey data release, https://doi.org/10.5066/P91OLJN3.

Beard, L.S., and Lucchitta, I., 1993, Geologic map of the Valentine Southeast quadrangle, Mohave County, Arizona: U.S. Geological Survey Geologic Quadrangle Map 1711, scale 1:24,000, accessed February 1, 2018 at https://ngmdb.usgs. gov/Prodesc/proddesc_1216.htm.

Billingsley, G.H., Block, D.L., and Dyer, H.C., 2006, Geologic map of the Peach Springs 30' x 60' quadrangle, Mohave and Coconino Counties, northwestern Arizona: U.S. Geological Survey Scientific Investigations Map 2900, scale 1:100,000, accessed February 1, 2018 at https://pubs.usgs. gov/sim/2006/2900/.

Bills, D.J., and Macy, J.P., 2016, Hydrogeologic framework and characterization of the Truxton aquifer on the Hualapai Reservation, Mohave County, Arizona: U.S. Geological Survey Scientific Investigations Report 2016-5171, 57 p., https://doi.org/10.3133/sir20165171.

Caine, J.S., Evans, J.P., and Forster, C.B., 1996, Fault zone architecture and permeability structure: Geology, v. 24, no. 11, p. 1025-1028, https://doi.org/10.1130/00917613(1996)024<1025:FZAAPS>2.3.CO;2.

Christiansen, A.V., and Auken, E., 2012, A global measure for depth of investigation: Geophysics, v. 77, no. 4, p. WB171177. https://doi.org/10.1190/geo2011-0393.1.

Elston, D.P., and Young, R.A., 1991, Cretaceous-Eocene (Laramide) landscape development and Oligocene-Pliocene drainage reorganization of Transition Zone and Colorado Plateau, Arizona: Journal of Geophysical Research, Solid Earth, v. 96, no. B7, p. 12389-12406, https://doi. org/10.1029/90JB01978.

Fenton, C.R., Webb, R.H., Pearthree, P.A., Cerling, T.E., and Poreda, R.J., 2001, Displacement rates on the Toroweap and Hurricane faults - Implications for Quaternary downcutting in the Grand Canyon, Arizona: Geology, v. 29 , no. 11, p. 1035-1038, https://doi.org/10.1130/00917613(2001)029<1035:DROTTA>2.0.CO;2.

Huntoon, P.W., 1977, Cambrian stratigraphic nomenclature and ground-water prospecting failures on the Hualapai Plateau, Arizona: Groundwater, v. 15, no. 6, p. 426-433, https://doi.org/10.1111/j.1745-6584.1977.tb03190.x.

Kennedy, J.R., 2020, Gravity surveys and depth to bedrock in the Truxton basin, northwestern Arizona, chap. C of Mason, J.P., ed., Geophysical surveys, hydrogeologic characterization, and groundwater flow model for the Truxton basin and Hualapai Plateau, northwestern Arizona: U.S. Geological Survey Scientific Investigations Report 2020-5017, 10 p., https://doi.org/10.3133/sir20205017C. 
Knight, J.E., 2020, Simulation of groundwater-level changes from projected groundwater withdrawals in the Truxton basin, northwestern Arizona, chap. E of Mason, J.P., ed., Geophysical surveys, hydrogeologic characterization, and groundwater flow model for the Truxton basin and Hualapai Plateau, northwestern Arizona: U.S. Geological Survey Scientific Investigations Report 2020-5017, 39 p., https:// doi.org/10.3133/sir20205017E.

Mason, J.P., Bills, D.J., and Macy, J.P., 2020, Geology and hydrology of the Truxton basin and Hualapai Plateau, northwestern Arizona, chap. B of Mason, J.P., ed., Geophysical surveys, hydrogeologic characterization, and groundwater flow model for the Truxton basin and Hualapai Plateau, northwestern Arizona: U.S. Geological Survey Scientific Investigations Report 2020-5017, 9 p., https://doi. org/10.3133/sir20205017B.

Mason, J.P., Knight, J.E., Ball, L.B., Kennedy, J.R., Bills, D.J., and Macy, J.P., 2020, Groundwater availability in the Truxton basin, northwestern Arizona, chap. A of Mason, J.P., ed., Geophysical surveys, hydrogeologic characterization, and groundwater flow model for the Truxton basin and Hualapai Plateau, northwestern Arizona: U.S. Geological Survey Scientific Investigations Report 2020-5017, 14 p., https:// doi.org/10.3133/sir20205017A.

Natural Resource Consulting Engineers, 2011, Evaluation of the Peach Springs groundwater supply on the Hualapai Reservation: Natural Resource Consulting Engineers, prepared for the Hualapai Tribal Council, $102 \mathrm{p}$.

Palacky, G.J, 1988, Resistivity characteristics of geologic targets, chap. 3 of Nabighian, M.N., and Corbett, J.D., eds., Electromagnetic methods in applied geophysics - Theory (vol. 1): Tulsa, Okla., Society of Exploration Geophysics, p. $52-129$.
Richard, S.M., Reynolds, S.J., Spencer, J.E., and Pearthree, P.A., 2000, Geologic map of Arizona: Arizona Geological Survey, scale 1:100,000, accessed February 1, 2018 at http://repository.azgs.az.gov/uri_gin/azgs/dlio/1705.

Sørensen, K., and Auken, E., 2004, SkyTEM-A new highresolution helicopter transient electromagnetic system: Exploration Geophysics, v. 35, no. 3, p. 194-202, https:// doi.org/10.1071/EG04194.

Stenner, H.D., Lund, W.R., Pearthree, P.A., and Everitt, B.L., 1999, Paleoseismologic investigations of the Hurricane Fault in northwestern Arizona and southwestern Utah: Arizona Geological Survey Open-File Report 99-8, 140 p.

Twenter, F.R, 1962, Geology and promising areas for groundwater development in the Hualapai Indian Reservation, Arizona: U.S. Geological Survey Water Supply Paper 1576A, available online at https://doi.org/10.3133/wsp1576A.

U.S. Geological Survey, 2016, U.S. Geological Survey National Elevation Data: accessed January 16, 2018 at https://datagateway.nrcs.usda.gov/

Viezzoli, A., Kaminski, V., and Fiandaca, G., 2017, Modeling induced polarization effects in helicopter time domain electromagnetic data-Synthetic case studies: Geophysics, v. 82, no. 2, p. E31-E50. https://doi.org/10.1190/geo20160096.1.

Young, R.A., 2001, Geomorphic, structural, and stratigraphic evidence for Laramide uplift of the southwestern Colorado Plateau margin in northwestern Arizona in Erskine, M.C., Faulds, J.E., Bartley, J.M., and Rowley, P.D., eds., The geologic transition, high plateaus to Great Basin-A symposium and field guide, the Mackin Volume: Salt Lake City, Utah, Utah Geological Association, p. 227-237.

Young, R.A., and Hartman, J.H., 2014, Paleogene rim gravel of Arizona-Age and significance of the Music Mountain Formation: Geosphere, v. 10, no. 5, p. 870-891, https://doi. org/10.1130/GES00971.1. 
Menlo Park Publishing Service Center, California

Manuscript approved for publication February 24, 2020

Edited by Regan Austin

Layout and design by Kimber Petersen and Cory Hurd Illustration support by JoJo Mangano 
용

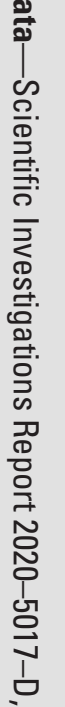

